\title{
Article \\ Granular Calcite: A New Cultural Practice to Improve the Physicochemistry of the Peat Substrate, Growth and Morphophysiological Quality of White Spruce Seedlings in Forest Nurseries
}

\author{
Mohammed S. Lamhamedi *, Mario Renaud and Isabelle Auger \\ Direction de la Recherche Forestière, 2700, rue Einstein, Québec, QC G1P 3W8, Canada; \\ mariorenaud@hotmail.com (M.R.); isabelle.auger@mffp.gouv.qc.ca (I.A.) \\ * Correspondence: mohammed.lamhamedi@mffp.gouv.qc.ca
}

Citation: Lamhamedi, M.S.; Renaud, M.; Auger, I. Granular Calcite: A New Cultural Practice to Improve the Physicochemistry of the Peat Substrate, Growth and Morphophysiological Quality of White Spruce Seedlings in Forest Nurseries. Land 2021, 10, 661. https://doi.org/10.3390/land10070661

Academic Editors: Diane L. Haase, Jeremiah R. Pinto and Owen T. Burney

Received: 1 June 2021

Accepted: 18 June 2021

Published: 22 June 2021

Publisher's Note: MDPI stays neutral with regard to jurisdictional claims in published maps and institutional affiliations.

Copyright: (c) 2021 by the authors. Licensee MDPI, Basel, Switzerland. This article is an open access article distributed under the terms and conditions of the Creative Commons Attribution (CC BY) license (https:// creativecommons.org/licenses/by/ $4.0 /)$.

\begin{abstract}
Growing Picea glauca seedlings poses many challenges for forest nursery managers, including reaching the target height at the end of the first growing season $(1+0)$ and the homogeneity and uniformity of seedling growth. To increase growth and morphophysiological quality of white spruce seedlings $(1+0)$, emphasis was placed on improving the physicochemistry of the acidic peat substrate by replacing silica with granular calcite as a covering material. The objective of our study is to compare the effects of silica and calcite on the physicochemistry of the peat substrate, as well as on growth and mineral nutrition of white spruce seedlings $(1+0)$ under forest nursery conditions. Three treatments were used to cover the cavities of large white spruce seedlings produced in containers: silica ( $29 \mathrm{~g} /$ cavity; control treatment), calcite ( $24 \mathrm{~g} /$ cavity) and calcite $+(31 \mathrm{~g} /$ cavity) At the end of the first growing season, the two calcite treatments significantly increased the total dry mass $(28 \%)$, roots $(27 \%)$ and shoot $(29 \%)$ dry masses and height $(24 \%)$ compared to silica treatments. Average calcium concentration and content of calcite treatments were significantly higher than that of silica treatment.
\end{abstract}

Keywords: Picea glauca; peat substrate; granular calcite; physicochemical parameters; growth; logistical models; mineral nutrition; forest nursery

\section{Introduction}

In Quebec forest nurseries, white spruce (Picea glauca (Moench) Voss) is one of the most demanding species in terms of water and mineral nutrients during the first and second growing seasons when producing containerized large seedlings [1-4]. In addition, nursery managers face additional challenges, including a short growing season in northern climates, individual genetic variability in several growth variables of white spruce seedlings [5-7], drastic fluctuations of environmental variables and some physicochemical properties of the substrate (substrate water content and fertility, $\mathrm{pH}$, electrical conductivity and cation exchange capacity) [2,8]. To reduce losses of large seedlings that do not meet the 27 morphophysiological quality standards at the end of the second growing season [9] of white spruce, nursery managers aim to achieve an average height of 9 to $10 \mathrm{~cm}$ at the end of the first growing season as well as an appreciable dry mass of roots (500-600 mg) and shoots (600-800 mg). Nursery managers are always on the lookout for searching technological innovations and cultivation techniques that are cost effective and easy to implement on an operational scale during the first $(1+0)$ and second $(2+0)$ growing season of white spruce seedlings.

The cavities of tree seedlings produced in containers are usually covered with crystalline silica because it constitutes an excellent material for covering seeds. Silica is distinguished by several properties (inert material, does not present a major obstacle during seed germination, allows good aeration on the surface of cavities, its pale whitish color allows to 
reflect incident light rays and reduces the temperature at seed level during germination). In recent years (2010 to 2017), Quebec forest nurseries have been faced with a serious problem related to the poor quality of the available silica. Our laboratory analyses have shown that this poor quality silica is characterized by a basic $\mathrm{pH}$, whereas the normal $\mathrm{pH}$ of the silica should not exceed $5.5[10,11]$. This has substantially decreased the seed germination rate, as well as shoot and root growth of different forest species $[10,11]$. The poor quality silica used in forest nurseries has probably been impregnated or treated with chemicals (basic detergents or basic anti-dust products) which interfere with germination, growth of roots and shoots and the mineral nutrition (purple coloring of needles) of tree seedlings [11]. When these symptoms appear, it is already too late for seedlings to recover and meet the norms and criteria of morphophysiological quality before their delivery for reforestation. For example, when the cavities were covered with poor quality silica, at the end of the second growing season, the height of large white spruce $(2+0)$ seedlings did not exceed 10 to $15 \mathrm{~cm}$ and the root-plug cohesion was inadequate. Technical readjustments did not help in achieving the growth objectives and norms of the large seedlings (irrigation, fertilization, etc.) $[10,11]$. These large seedlings should have reached an average height of $35 \mathrm{~cm}$, according to the contractual morphophysiological quality norms in force in Quebec. In the Province of Quebec chemical herbicides are banned and large seedlings are used because they can overtop herbaceous vegetation better than small planting stock [12,13]. Therefore, forest nurseries are intensively looking for alternative covering materials to silica.

In order to improve the growth of tree seedlings produced in acidic peat growing media, different cultural practices have focused on increasing the $\mathrm{pH}$ to increase the availability and absorption of mineral nutrients [14-19]. This can be conferred by adding powdered calcium $\left(\mathrm{CaCO}_{3}\right)$ or dolomitic $\left(\mathrm{CaMg}\left(\mathrm{CO}_{3}\right)_{2}\right)$ lime during the preparation of the substrates [15]. Our previous study showed that the use of granular calcite, as a covering material, significantly improved the external colonization of root-plugs by ectomycorrhizal fungi and the growth of white spruce seedlings at the end of their second growing season under forest nursery conditions $[20,21]$. However, the better growth and mineral status of $(2+0)$ seedlings were attributed to the increase in the root absorption surface (water and mineral elements) generated by the extramatrical phase of the ectomycorrhizal fungi. The presence of granular calcite also clearly increased physicochemical properties $\left(\mathrm{pH}, \mathrm{CO}_{2}\right.$ and calcium concentration) of the substrate [20]. However, ectomycorrhizal colonization of the roots produced under tunnel conditions was absent during the first growing season $[20,21]$. For this purpose, could the use of granular calcite alone increase the growth of roots and shoot of white spruce seedlings $(1+0)$ during the first growing season while improving the physicochemical properties of the rhizosphere?

However, we need to better understand the effect of granular calcite on the growth of white spruce seedlings $(1+0)$ and how this material affects $\mathrm{pH}$ and fertility variation of the substrate, particularly micro vertical changes across root-plugs after seed germination. Unlike the second growing season during which the growth of the roots is limited by the volume of the container cavity (350 cc) $[20,21]$, this volume/cavity will not be a limiting factor for the growth and development of roots during the first growing season. We hypothesize that calcite coverage during the first growing season could improve the physicochemistry of the acidic peat substrate and increase root and shoot growth of white spruce seedlings $(1+0)$ compared to those treated with silica. In addition, this study will allow the development of growth models during the first growing season (height, diameter, and shoot and roots dry masses) in response to the use of granular calcite. These models are widely used by nursery managers as growth standards and are crucial to optimizing cultural practices (irrigation, fertilization, preconditioning to water stress, etc.) and meeting morpho-physiological quality standards of seedlings [9]. This will help improve the profitability of forest nurseries.

The objectives of this study are to: (i) compare the effects of calcite and silica on variations in $\mathrm{pH}$ gradient and substrate fertility across root-plugs, growth and mineral nutrition of white spruce seedlings $(1+0)$ during the first growing season in a forest 
nursery; (ii) adjust the logistic growth models of the seedlings according to the covering material (silica, calcite) for a better monitoring of crop management during the first growing season; (iii) compare the parameters of the models related to the allocation of dry matter between the shoot and the roots according to the covering material; and (iv) develop operational recommendations to improve the growth, mineral nutrition and quality of white spruce seedlings $(1+0)$.

\section{Materials and Methods}

\subsection{Plant Material, Covering Material and Experimental Design}

In Quebec, white spruce seeds come from first and second generation seed orchards. Before their delivery to forest nurseries, these seeds are treated at the Berthier Forest Seed Center in the province of Quebec (Canada). The quality of the seeds is evaluated according to the standards of the International Seed Testing Association (ISTA). After sowing the white spruce seeds (seedlot: EPB-V3-EST-2-0; production code GP35EPB14-P85) in containers (model IPL 25-310, Saint-Damien, QC, Canada; 25 cavities, $310 \mathrm{~cm}^{3} /$ cavity; 206 cavities or seedlings $/ \mathrm{m}^{2}$ ). This container has a square format (length of each side: $348.2 \mathrm{~mm}$, height: $126 \mathrm{~mm}$ ). The cavities of containers were filled with a mixture of peat-based substrate and vermiculite $(80 \%: 20 \%, v / v)$, and bulk density was adjusted to $0.10 \mathrm{~g} / \mathrm{cm}^{3}$. The $\mathrm{pH}_{\text {water }}$ of the initial substrate prior to seeding was 3.4. These containers were placed in a hemispherical dome-shaped tunnel (length: $100 \mathrm{~m}$, width: $10 \mathrm{~m}$, capacity: 5130 containers) of the Grandes-Piles governmental forest nursery (latitude: $46^{\circ} 43^{\prime} 54^{\prime \prime} \mathrm{N}$; longitude: $72^{\circ} 42^{\prime} 06^{\prime \prime} \mathrm{W}$ ).

The seeds were covered with one of three types of materials: crystalline silica $\left(\mathrm{SiO}_{2}\right.$, $29 \mathrm{~g} /$ cavity; control treatment), calcite $\left(\mathrm{CaCO}_{3}, 24 \mathrm{~g} /\right.$ cavity) and calcite+ $\left(\mathrm{CaCO}_{3}, 31 \mathrm{~g} /\right.$ cavity) . Dolomitic calcite $\left(\mathrm{CaMg}\left(\mathrm{CO}_{3}\right)_{2}\right)$ was not tested in this project. The particle size distribution of the covering materials (silica and calcite) is described in detail by Lamhamedi et al. [20]. Treatments (silica, calcite and calcite+) were randomly distributed within each of the five complete blocks of the experimental design. Each treatment consisted of 27 containers (25-310 cc) per block, for a total of 10125 seedlings throughout the entire experimental design (excluding buffer zones). To eliminate border effects, buffer zones ( 27 containers / zone) were added between treatments and between blocks. After germination and thinning, the average occupancy rate of the container cavities for the three treatments (silica, calcite and calcite+) was $99.33 \%$ [20].

During the first growing season, the tunnel was covered with a 4 mm-thick milk-white polyethylene, with an incident light diminishing factor of 50-55\% (Ginegar Plastic Products Ltd., Northbrook, IL, USA, multi-layer greenhouse cover film, type UVA/ white 45\%). The cover was retractable on both sides of the tunnel to increase ventilation and control the air temperature inside. The cover was removed around mid-October, 2014, so the plants were exposed to outdoor conditions during their first winter and second growing season.

\subsection{Assessment of Environmental Variables}

In Quebec, white spruce seedlings are produced in a tunnel during the first growing season. The tunnel was not removed until around 6 October 2014. Environmental variables inside and outside the tunnel were continuously recorded by two data acquisition systems (model CR-10X, Campbell Scientific, Logan, UT, USA) every five minutes, and an hourly average was calculated and recorded. Different probes for environmental monitoring were installed inside and outside the tunnel (air temperature at $2 \mathrm{~m}$, relative humidity, density of the active photosynthetic flux, active photosynthetic radiation, three probes for monitoring temperatures in the substrate and as much for the temperature at the level of the seedlings). Two rain gauges (Model TE52M, Texas Instruments, Dallas, TX, USA) for monitoring watering and fertilization were also installed.

In addition, 15 probes (iButton model, Innovation Drive, Whitewater, WI, USA) were installed directly under the silica or calcite covering the seeds, in each block, to record the 
temperature variations, at a frequency of $15 \mathrm{~min}$. These probes are autonomous and are therefore not connected to the data acquisition system.

\subsection{White Spruce Seedling Production}

The seedlings were produced using the standard nursery cultural techniques used in Quebec to produce large white spruce seedlings in containers $[1,2,20]$. Irrigation and fertilization were carried out using a robot (Aquaboom model, Industrie Harnois, SaintThomas-de-Joliette, QC, Canada) to eliminate the effects of spatial variability in the substrate's water content [15]. The robot's coefficient of uniformity varied from $95 \%$ to $98 \%$. Substrate water content $(\%, v / v)$ was adjusted for each seedling growth stage during the first growing season $(1+0)$ and monitored by gravimetry prior to each irrigation [22].

The fertilization regime was adjusted every two weeks during this first growing season $(1+0)$ using the PLANTEC software, according to the growth stages [23]. By the end of the first growing season, each seedling received $47.3 \mathrm{mg}$ of nitrogen $(\mathrm{N}: 25.0 \mathrm{mg}$ $\left.\mathrm{N}-\mathrm{NH}_{4}, 22.3 \mathrm{mg} \mathrm{N}-\mathrm{NO}_{3}\right), 10.6 \mathrm{mg}$ of phosphorus (P), $15.2 \mathrm{mg}$ of potassium (K) and $0.1 \mathrm{mg}$ of magnesium (Mg), as well as micronutrients (mg/plant) (magnesium: 0.10, manganese: 0.04 , copper: 0.04 , iron: 0.23 and boron: 0.28 ). The average flow rate of the injector for fertilization was $0.3 \mathrm{~L} / \mathrm{min}$.

2.4. Assessment of Variations in the $p H$ Gradient and the Fertility of the Substrate Depending on the Cover Material and the Height Level of the Root-Plug

Once seed germination was complete, a first sampling was done on 2 June 2014, before the start of the first fertilization treatment, at a rate of one container/treatment/block ( 15 containers in total: 1 container/treatment $\times 3$ treatments/block $\times 5$ blocks). A second sampling was carried out after fertilization on 25 June 2014.

In the laboratory, the seedlings were first gently removed from the cavities as the secondary roots were not yet well developed, and then the calcite and silica covering the substrate were completely removed. After, the containers were stored in the freezer (temperature: -18 to $-20^{\circ} \mathrm{C}$ ) for $14 \mathrm{~h}$ to freeze the substrate-plug. Freezing the plugs made it easier to extract them from the container cavities. Then, each substrate-plug was subdivided into three equal sections (top, center and bottom) using a saw. The $\mathrm{pH}$ in water $\left(\mathrm{pH}_{\text {water }}\right)$ and $\mathrm{CaCl}_{2}(\mathrm{pHCaCl})$, as well as the different mineral nutrients $\left(\mathrm{N}_{\min }, \mathrm{P}, \mathrm{K}, \mathrm{Ca}\right.$ and $\mathrm{Mg}$ ) were determined on composite samples (25 substrate-plugs/treatment/block) for each of the three sections (top, center and bottom), for a total of 45 samples per sampling date. In addition to the $\mathrm{pH}_{\text {water }}$ commonly used by forest nurseries, the $\mathrm{pHCaCl}_{2}$ was also determined to better characterize and approximate the real variations in the physicochemistry of the rhizosphere after hydrolysis of calcite. The advantages of the determination of $\mathrm{pHCaCl}_{2}$ are described in detail by Kalra and Maynard [24].

\subsection{Fertility and Physicochemical Properties of the Substrate, Growth and Mineral Nutrition of White Spruce Seedlings $(1+0)$}

The physico-chemical variables of the substrate related to the fertility, as well as the morpho-physiological variables of the seedlings (growth, mineral nutrition) were determined using eight destructive samples between 14 July and 27 October 2014 during the first growing season. Mineral nutrient analyses of seedlings and substrate were conducted at the Laboratoire de chimie organique et inorganique (organic and inorganic chemistry laboratory) of the Direction de la recherche forestière (Quebec forest research branch), using the methods described in Lamhamedi et al., 2013, among others [22,25].

During each sampling, one container per treatment was randomly selected from each experimental block. In each sampled container, 15 of the 25 seedlings were randomly selected, for a total of 225 seedlings per sampling date (or 75 seedlings/treatment). The position of the container and the 15 sampled cavities were randomly selected. The same container and cavity positions were used for all block-treatment combinations on a given date. 
These samples were used to measure several morpho-physiological variables such as height (15 seedlings/block/treatment), diameter (15 seedlings/block/treatment), shoot and root dry mass (five composite samples of three seedlings per block/treatment), the mineral nutrition of the seedlings (one composite sample of 15 seedlings per block/treatment), as well as the fertility and physico-chemical properties of the substrate (one composite sample of 15 substrate-plugs per block/treatment). Shoot and root dry masse were determined after drying for $48 \mathrm{~h}$ at $60^{\circ} \mathrm{C}$.

The total nitrogen concentration was determined by burning the sample at high temperature using the LECO Trumac Nitrogen Analyzer (Leco Corporation, St-Joseph, MI, USA). The remaining elements $(\mathrm{P}, \mathrm{K}, \mathrm{Ca}, \mathrm{Mg}$ ) were determined using a plasma atomic emission spectrometer (model ICAP 9000, Thermo Instruments, Franklin, MA, USA). The mineral content was calculated for each element (concentration multiplied by dry mass) thus reflecting the amount of mineral elements absorbed or contained in a mass of plant material [26]. The use efficiency of the major mineral nutrients in shoots and roots, particularly for nitrogen (NUE), phosphorus (PUE) and potassium (KUE) was then calculated as the ratio between the dry mass of the shoot or roots and the content of this element in the shoot or roots [27].

\subsection{Statistical Analyses and Modelling of Growth Variables \\ 2.6.1. Analysis of Variance}

We used the same statistical analysis approach described by Lamhamedi et al. [20]. To assess the effects of the cover treatment and the sampling date on substrate fertility variables and seedling morpho-physiological variables (growth, mineral nutrition, etc.) measured during the first growing season. Variance analyses were performed using mixed linear models with the MIXED procedure of SAS/STAT version 14.1 (SAS Institute Inc., Cary, NC, USA, 2015) and the average of samples per block/treatment. Treatment, sampling date, and their interaction were considered fixed effects, while the block and the interaction between the block and treatment was considered to be random. A model with a fixed effect (treatment) and a random block effect was used to analyze the percentage of ectomycorrhizal colonization. In all models, the number of degrees of freedom of the denominator for the fixed effects tests was calculated using the Satterthwaite method. The number of degrees of freedom at the denominator is therefore specific to each variable analyzed.

When the fixed effect was significant at the 5\% threshold, orthogonal contrasts were performed. The treatment effect was divided into two contrasts: mean calcite/calcite+ vs. silica and calcite vs. calcite+. If the interaction between date and treatment was significant, treatment contrasts were performed for each date allowing to better identify the phases of growth or the dates when the treatments differed in their effect on growth, mineral nutrition and the physico-chemistry of the growing substrate. The effect of time was divided into two contrasts: linear and quadratic. When the interaction between treatment and date was significant, the temporal evolution was compared between the treatments using these two contrasts. Thus, the linear effect and the quadratic effect of time were compared for calcite/calcite+ vs. silica treatments, and for calcite vs. calcite+ treatments. The contrasts tests were based on an adjustment for multiple comparisons using a simulation method with the ADJUST = SIMULATE option of the LSMEANS statement of the MIXED procedure in SAS/STAT (version 14.1).

The hypotheses of variance normality and homogeneity were checked graphically. Where necessary, a residual variance by date was estimated to take into account variance heterogeneity. Preliminary analyses showed that sampling dates were not associated to a temporal correlation between the data. Pearson correlation coefficients were calculated between the substrate's different physicochemical variables.

The variations of the $\mathrm{pH}$ gradient and the fertility of the substrate according to the material of the covering and the level of height of the substrate-plug (top, center and bottom) were analyzed using linear mixed models with the MIXED procedure of SAS/STAT version 14.1. Coverage treatment, date of sampling, level of substrate-plug (top, center 
and bottom) and their interactions were considered as fixed effects in the models while block and the interaction between block and cover treatment were considered as random effects. The correlation between the observations of the same combination of a block, a treatment and a date was taken into account using a covariance matrix on the residual errors (unstructured correlation matrix).

\subsubsection{Modeling of Growth Variables and Dry Matter Allocation}

The temporal evolution of each growth variable $(y)$ was modeled with the logistic function (1) as described by Lamhamedi et al. [20] (using a mixed nonlinear model and the NLMIXED procedure of SAS/STAT version 14.1) (SAS Institute Inc., Cary, NC, USA, 2015):

$$
y=\frac{a+u}{1+e^{-c(d a y-b)}}
$$

where parameters $a, b$, and $c$ are the asymptote, inflection point and growth rate, respectively. Parameter $u$ is the random effect of the interaction between the block and the treatment.

To test for differences in the kinetics of the assessed growth variables between the three treatments during the growing season, indicator variables were added to the model (2). These variables are defined as $i_{1}=1$ if (treatment $=$ calcite, otherwise, $i_{1}=0$, and $i_{2}=1$ if treatment $=$ calcite + , otherwise, $i_{2}=0$.

$$
y=\frac{a_{0}+a_{1} i_{1}+a_{2} i_{2}+u}{1+e^{-\left(c_{0}+c_{1} i_{1}+c_{2} i_{2}\right)\left(\text { day }-\left(b_{0}+b_{1} i_{1}+b_{2} i_{2}\right)\right)}}
$$

When no significant difference between calcite and calcite+ for a given parameter is observed, only one parameter common to both treatments was used $\left(a_{12}, b_{12}, c_{12}\right)$. The model was then simplified by removing the indicator variables that were not significant at $5 \%$ threshold. Models were adjusted to the dataset for the different sampling dates.

Residue normality and homogeneity of variance hypotheses were checked graphically. To account for the heterogeneity of the variances, the residual variance was weighted according to the variance observed at each date. Logistic model adjustment was checked graphically by comparing the predicted values with the averages observed at each time per treatment. A coefficient of determination $\left(R^{2}\right)(3)$ was calculated as follows:

$$
R^{2}=1-\left[\sum(y-\hat{y})^{2} / \sum(y-\bar{y})^{2}\right]
$$

where $\hat{y}$ is the value predicted by the model and $\bar{y}$ is the mean of $y$.

The comparison of the three cover treatments in terms of their effects on the allocation of dry matter between the shoots and the roots was carried out using logistic models on a logarithmic basis $[1,28]$ of these two growth variables $(4)$. The general logistic model is as follows:

$$
\ln (\text { mass_shoot })=\frac{a+u}{1+e^{-c(\text { ln }(\text { mass_root })-b)}}
$$

where mass shoot is the shoot dry mass, mass_root is the dry mass of the roots, a is the asymptote, $b$ the inflection point, c the allocation rate and $u$ the random effect of the interaction between the block and treatment. In order to check whether there are differences in allocation between the three recovery treatments, dummy variables were added to the model in the same way as in the logistic model of growth variables.

To generate these models, the data used corresponded to the measurements taken from the 5 composite samples of three seedlings for each block and treatment on a given date. Thus, 600 data items per treatment were used to generate models (5 composite samples $\times 5$ blocks $\times 3$ treatments $\times 8$ dates). The modeling was performed using the NLMIXED procedure of SAS/STAT version 14.1. 


\section{Results}

\subsection{Environmental Variables, Irrigation and Substrate Water Content}

The temperatures (maximum, average and minimum) of the air outside the tunnel (Figure 1) and those recorded at the seed-silica or calcite interface (Figure 2) showed relatively similar patterns of daily variations. However, the maximum tunnel temperatures, more specifically those recorded at the seed-silica or calcite interface (Figure 2), were generally higher than those observed outside (Figure 1). Freezing temperatures outside the tunnel were not observed until mid-September. However, inside the tunnel, these freezing temperatures were not recorded at the substrate-silica or calcite interface. Inside the tunnel, the average air relative humidity of the tunnel has generally varied between 50 and $98 \%$ while the average air temperature has generally fluctuated between 4 and $25^{\circ} \mathrm{C}$ (Figure 3).

The frequencies and amounts of water used during daily irrigation throughout the first growing season of white spruce seedlings $(1+0)$ are shown in Figure 4 . At the end of the growing season, the amount of water accumulated and received by the seedlings was $238 \mathrm{~mm}$. Thus, the average of substrate water content of the substrate (\%, volume/volume) varied between 33\% and 50\%, from May to October (Figure 5).

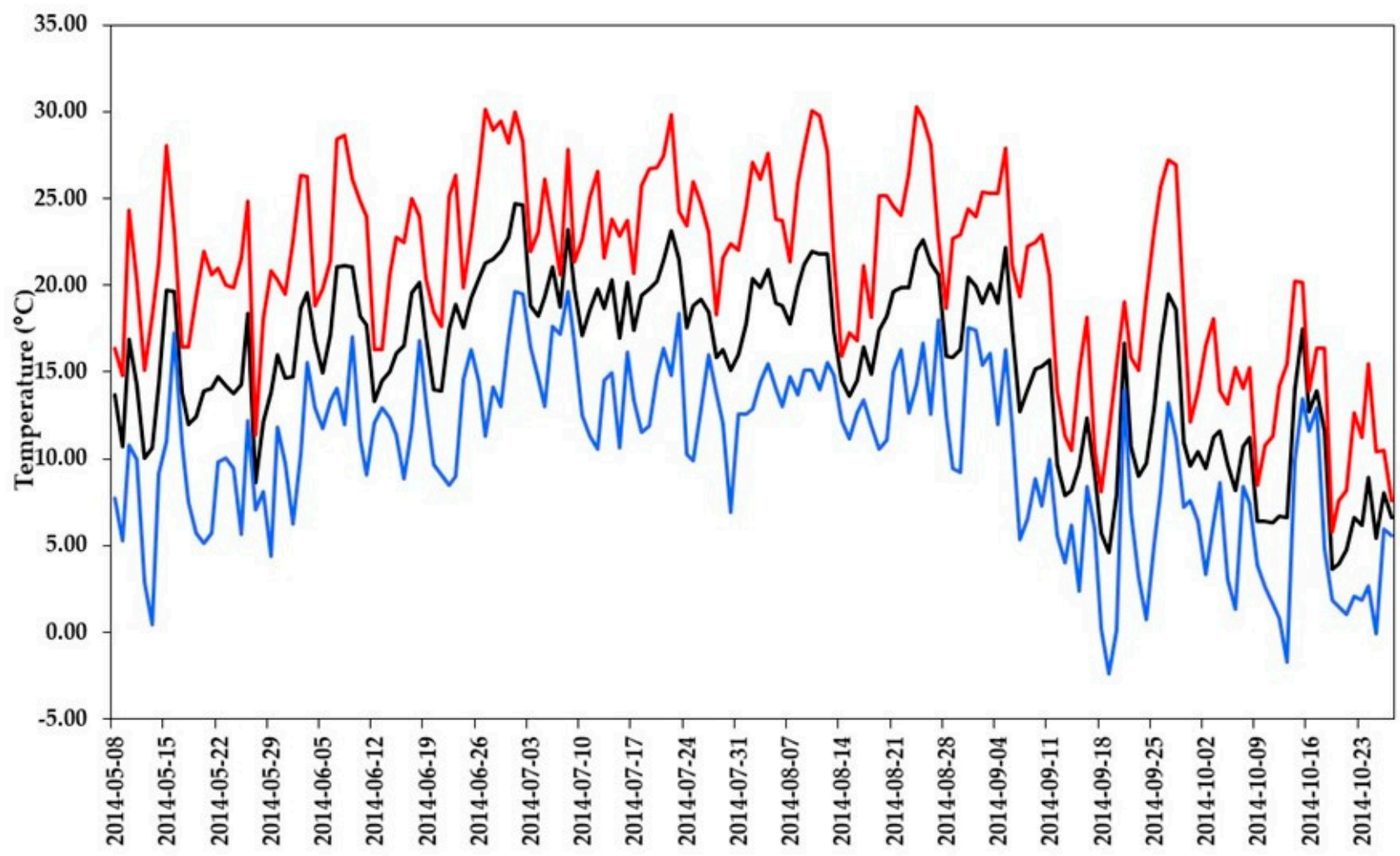

Figure 1. Variation of maximum (red), mean (black) and minimum (blue) daily air temperatures $2 \mathrm{~m}$ above the ground outside the tunnel at Grandes-Piles, a public forest nursery (Grandes-Piles, Québec, QC, Canada). 


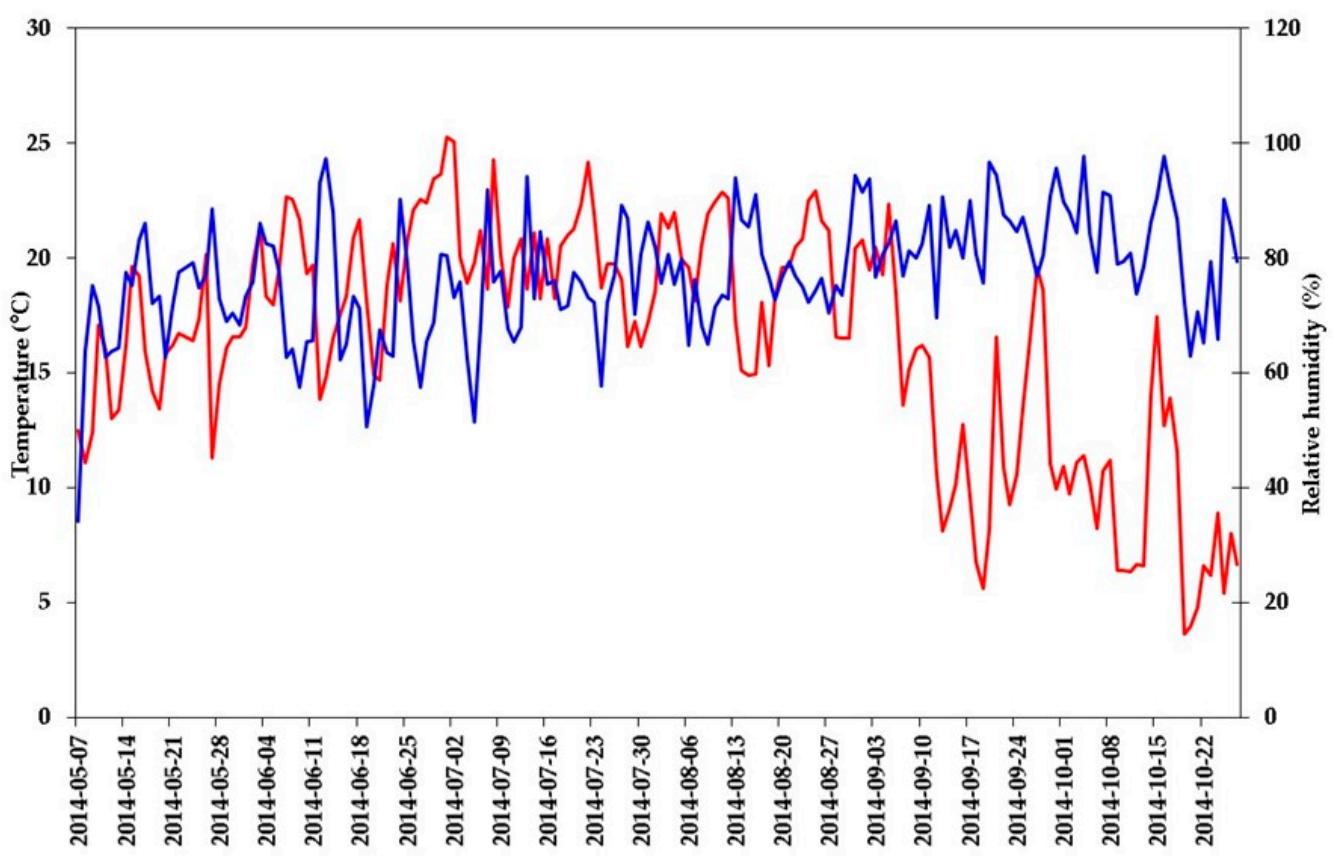

Figure 2. Variations in the relative humidity of the air (blue) and in the average air temperature (red) inside the tunnel during the first growing season of white spruce seedlings $(1+0)$.

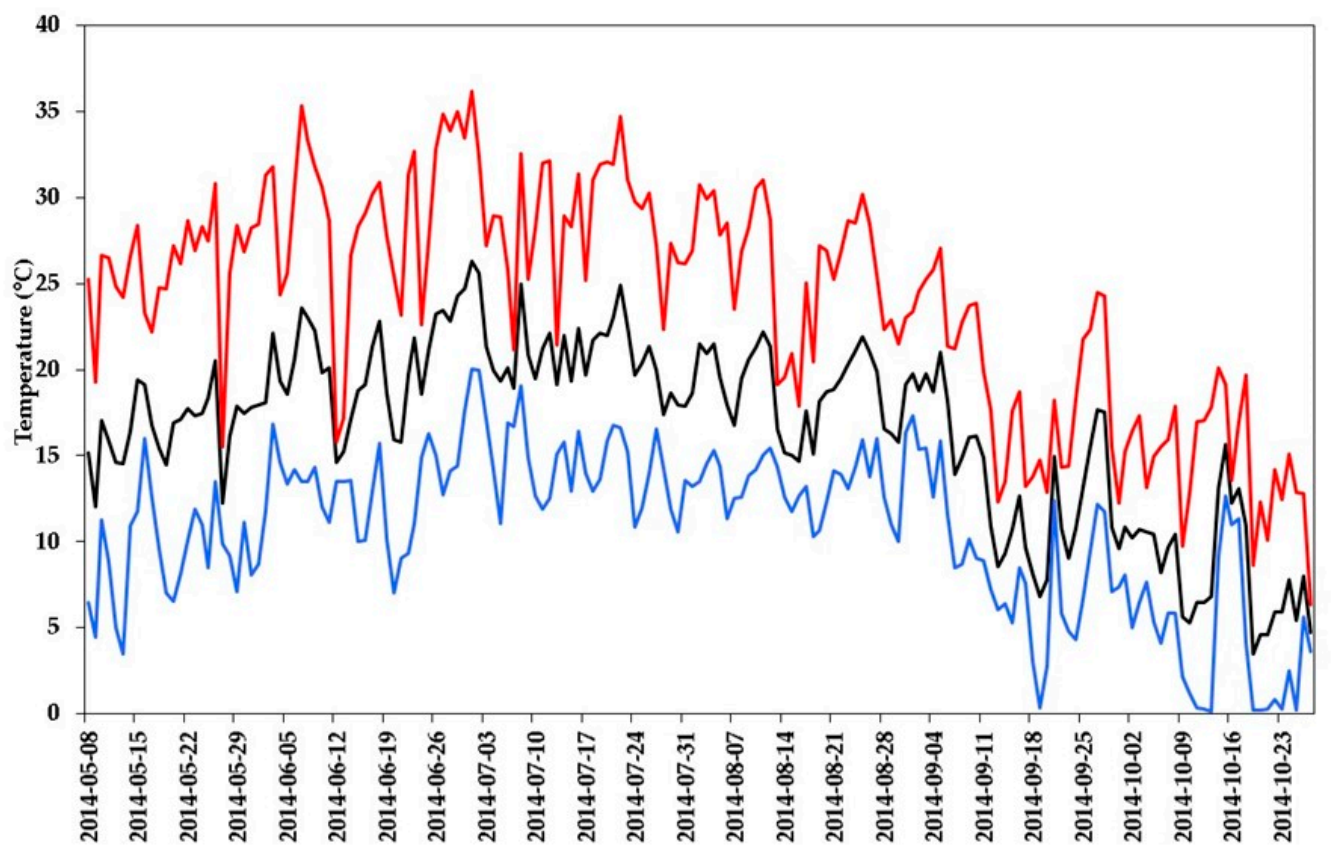

Figure 3. Variation of maximum (red), mean (black) and minimum (blue) daily temperatures at the substrate-cover material interface (Silica or material Calcite) during the first growing season of white spruce seedlings $(1+0)$ in a tunnel. 


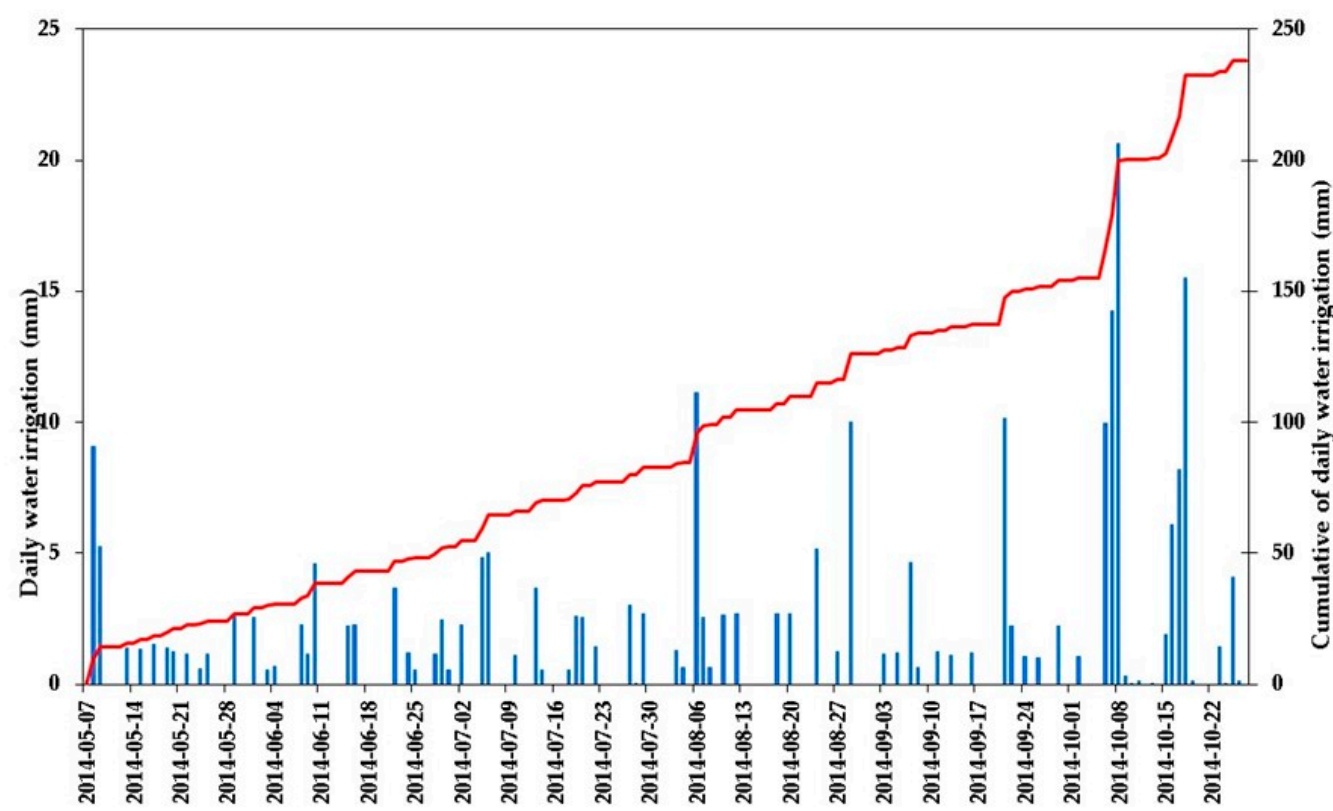

Figure 4. Frequencies and quantities of water used during daily irrigation (in blue), as well as the evolution of cumulative daily irrigation (in red) during the production of white spruce seedlings.

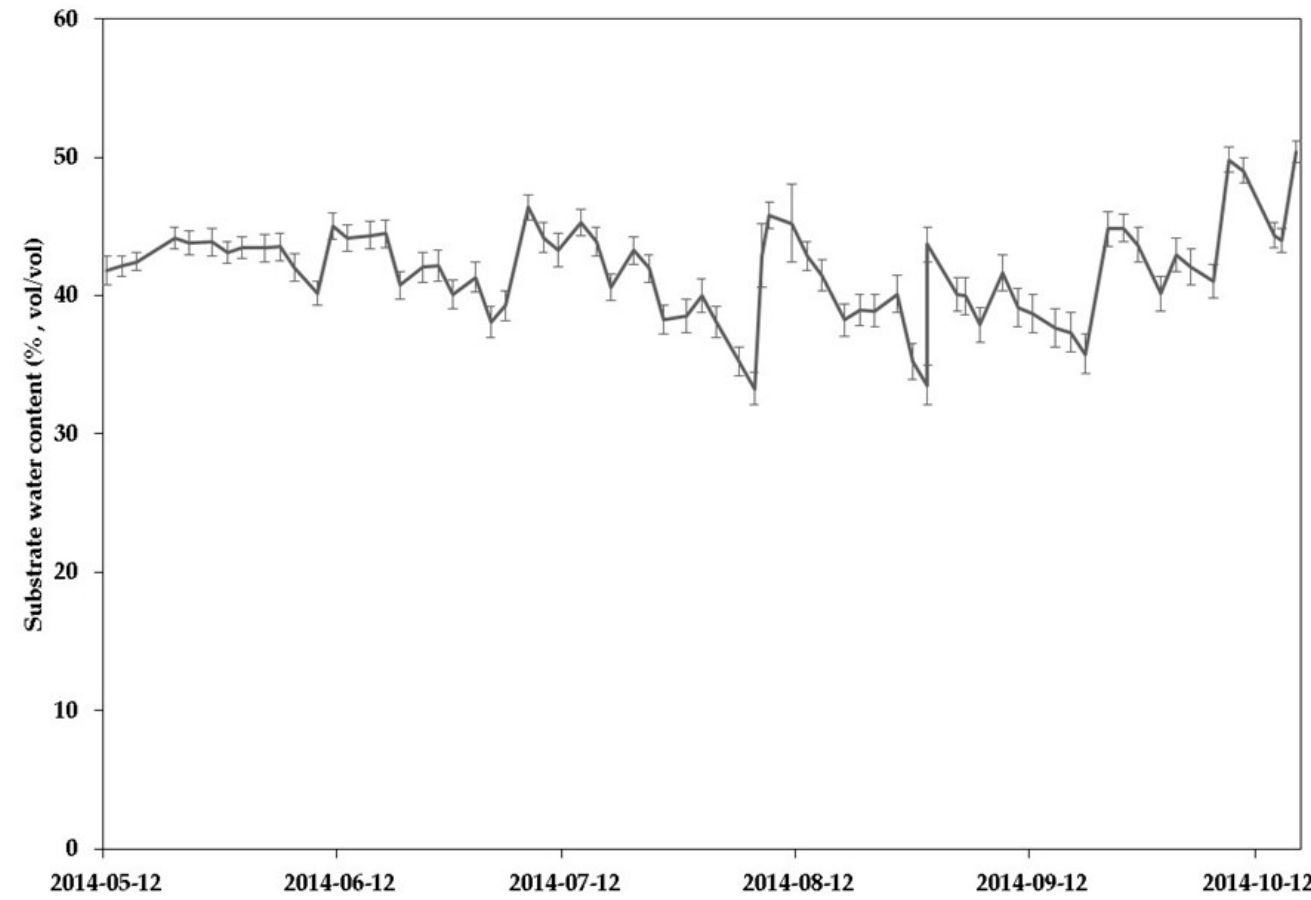

Figure 5. Variations in the mean water content of the substrate $(\%$, volume/volume) during the first growing season of white spruce seedlings $(1+0)$. Standard errors are indicated by bars $(n=6$ containers).

3.2. Assessment of Variations in the $p H$ Gradient and Substrate Fertility Depending on the Cover Material and the Level of the Substrate-Plug Height during the Germination Phase

Table 1 shows a significant interaction between the dates, the level of the substrate plug (top, center and, bottom) in the container cavity and the treatment (calcite+, calcite and silica) for all variables evaluated, except nitrogen in the ammonium form $\left(\mathrm{N}-\mathrm{NH}_{4}\right)$ and potassium $(\mathrm{K})$. 


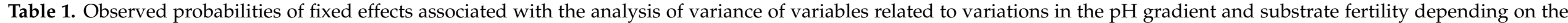
covering material (Silica, Calcite and Calcite+) and the level of substrate plug (top, center and bottom) during the germination phase.

\begin{tabular}{|c|c|c|c|c|c|c|c|c|c|c|c|}
\hline Source of Variation & $\mathrm{dln} *$ & dld * & $\mathrm{pH}_{\text {water }}$ & $\mathrm{pH}_{\mathrm{CaCl} 2}$ & $\begin{array}{c}\mathrm{N}-\mathrm{NH}_{4} \\
\text { (mg/kg) }\end{array}$ & $\begin{array}{l}\mathrm{N}-\mathrm{NO}_{3} \\
(\mathrm{mg} / \mathrm{kg})\end{array}$ & $\underset{(\mathrm{mg} / \mathrm{kg})}{\mathrm{Nmin}}$ & $\begin{array}{c}P \\
(\mathrm{mg} / \mathrm{kg})\end{array}$ & $\begin{array}{c}\mathrm{K} \\
(\mathrm{mg} / \mathrm{kg})\end{array}$ & $\begin{array}{c}\mathrm{Ca} \\
(\mathrm{mg} / \mathrm{kg})\end{array}$ & $\underset{(\mathrm{mg} / \mathrm{kg})}{\mathrm{Mg}}$ \\
\hline Treatment & 2 & 28.2 & 0.0536 & $<0.0001$ & 0.0152 & 0.0021 & $<0.0001$ & $<0.0001$ & $<0.0001$ & $<0.0001$ & $<0.0001$ \\
\hline Calcite/Calcite+ vs. Silica & $(1)$ & 28.2 & 0.0165 & $<0.0001$ & 0.0134 & 0.0005 & $<0.0001$ & $<0.0001$ & $<0.0001$ & $<0.0001$ & $<0.0001$ \\
\hline Calcite vs. Calcite+ & (1) & 28.2 & 0.9651 & 0.0436 & 0.0794 & 0.8400 & 0.5194 & 0.0052 & 0.0345 & 0.8246 & 0.9246 \\
\hline Date & 1 & 27.4 & $<0.0001$ & 0.1326 & $<0.0001$ & 0.0224 & 0.0004 & $<0.0001$ & $<0.0001$ & 0.0017 & 0.2380 \\
\hline Date $\times$ Treatment & 2 & 27.4 & 0.0117 & 0.0020 & 0.1534 & 0.0401 & 0.0351 & $<0.0001$ & 0.1652 & 0.0104 & 0.0238 \\
\hline Level & 2 & 29.2 & $<0.0001$ & $<0.0001$ & $<0.0001$ & $<0.0001$ & $<0.0001$ & $<0.0001$ & $<0.0001$ & $<0.0001$ & $<0.0001$ \\
\hline Level $\times$ Treatment & 4 & 29.2 & $<0.0001$ & $<0.0001$ & 0.0233 & 0.0072 & 0.0134 & $<0.0001$ & 0.0091 & 0.0005 & 0.0004 \\
\hline Date $\times$ Level $\times$ Treatment & 4 & 29.2 & 0.0064 & 0.0099 & 0.4317 & 0.0106 & 0.0040 & $<0.0001$ & 0.0843 & 0.0213 & 0.0182 \\
\hline
\end{tabular}

* dln: degrees of freedom of numerator; dld: degrees of freedom of denominator. The dld presented are those for $\mathrm{pH}_{\text {water }}$. They vary from 12.7 et 50.2 for other variables. 
For the latter, the interaction between level and treatment was significant. For $\mathrm{N}-\mathrm{NH}_{4}$, there was a significant difference between Calcite and Silica treatments in the bottom and center of the substrate plug, while it was significant in all levels for K (Supplementary Materials Table S1). In addition, there was a significant difference between the two calcite treatments in the substrate-plug for $\mathrm{K}$. For the mineral nutrients $\left(\mathrm{N}-\mathrm{NH}_{4}, \mathrm{~N}-\left(\mathrm{NO}_{2}+\mathrm{NO}_{3}\right)\right.$, $\mathrm{N}_{\text {min }}, \mathrm{P}, \mathrm{K}, \mathrm{Ca}$ and $\mathrm{Mg}$ ), there are some significant differences between treatments depending on levels and dates (Table S1).

The use of calcite as a cover material significantly affected variations in the $\mathrm{pH}$ gradient depending on the height level of the substrate-plug (top, center and bottom). Indeed, before fertilization, during the first sampling date (2 June 2014), the orthogonal contrasts showed that the mean water $\mathrm{pH}$ of the two calcite treatments (calcite and calcite+) was significantly higher than that of silica treatments at the top of the substrate-plug (Table S1). Thus, the water $\mathrm{pH}$ at the top of the substrate-plug of the three treatments (calcite+, calcite and silica) reached 5.9, 5.8 and 4.9, respectively (Figure 6a). In the case of $\mathrm{pHCaCl}_{2}$, this higher $\mathrm{pH}$ was maintained in the top and bottom of the substrate-plug (Table S1, Figure 6b). However, in the case of $\mathrm{pH}_{\text {water, }}$ this significant superiority is maintained in the three levels (top, center and bottom). On the other hand, after fertilization (25 June 2014) and excepting the $\mathrm{pH}$ water at the bottom of the substrate-plug, the difference between the calcite and silica treatments for the $\mathrm{pH}$ (water and $\mathrm{CaCl}_{2}$ ) of the different levels are not significant (Table S1).

At the first sampling, the mean concentration of calcium in the substrate of the two calcite treatments (calcite and calcite+) was significantly higher than that of silica treatments, regardless of the level of substrate plug (top, center and bottom) (Table S1). For example, the mean concentration of calcium in the upper section of the substrate plugs (top level) had reached $10.4 \mathrm{ppm}, 151.2 \mathrm{ppm}$ and $161.6 \mathrm{ppm}$ respectively for silica, calcite and calcite+. On the other hand, at the bottom of the substrate plug, these average concentrations for the three treatments did not exceed $16.2 \mathrm{ppm}, 23.0 \mathrm{ppm}$ and $20.8 \mathrm{ppm}$. After 23 days, the difference in calcium concentration in the top of the substrate plugs between calcite and silica, significantly decreased (silica: 18.6 ppm, calcite: 45.8 ppm and calcite+: 53.4 ppm), compared with that observed during the first sampling date (Table S1).

3.3. Fertility and Physicochemical Characteristics of the Substrate during the First Growing Season of White Spruce Seedlings $(1+0)$

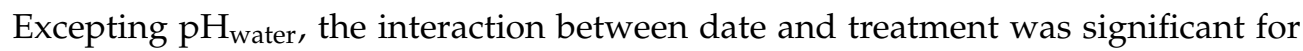
all other variables related to physico-chemistry and substrate fertility $\left(\mathrm{pH}_{\mathrm{CaCl} 2}\right.$, electrical conductivity, $\mathrm{N}-\mathrm{NH}_{4}, \mathrm{~N}-\mathrm{NO}_{3}, \mathrm{Nmin}, \mathrm{P}, \mathrm{K}, \mathrm{Ca}$ and $\mathrm{Mg}$ ) during the growth of white spruce seedlings $(1+0)$ (Table 2$)$. The effect of date (linear and quadratic) and treatment were significant for most of the physico-chemical and fertility variables of the substrate. 

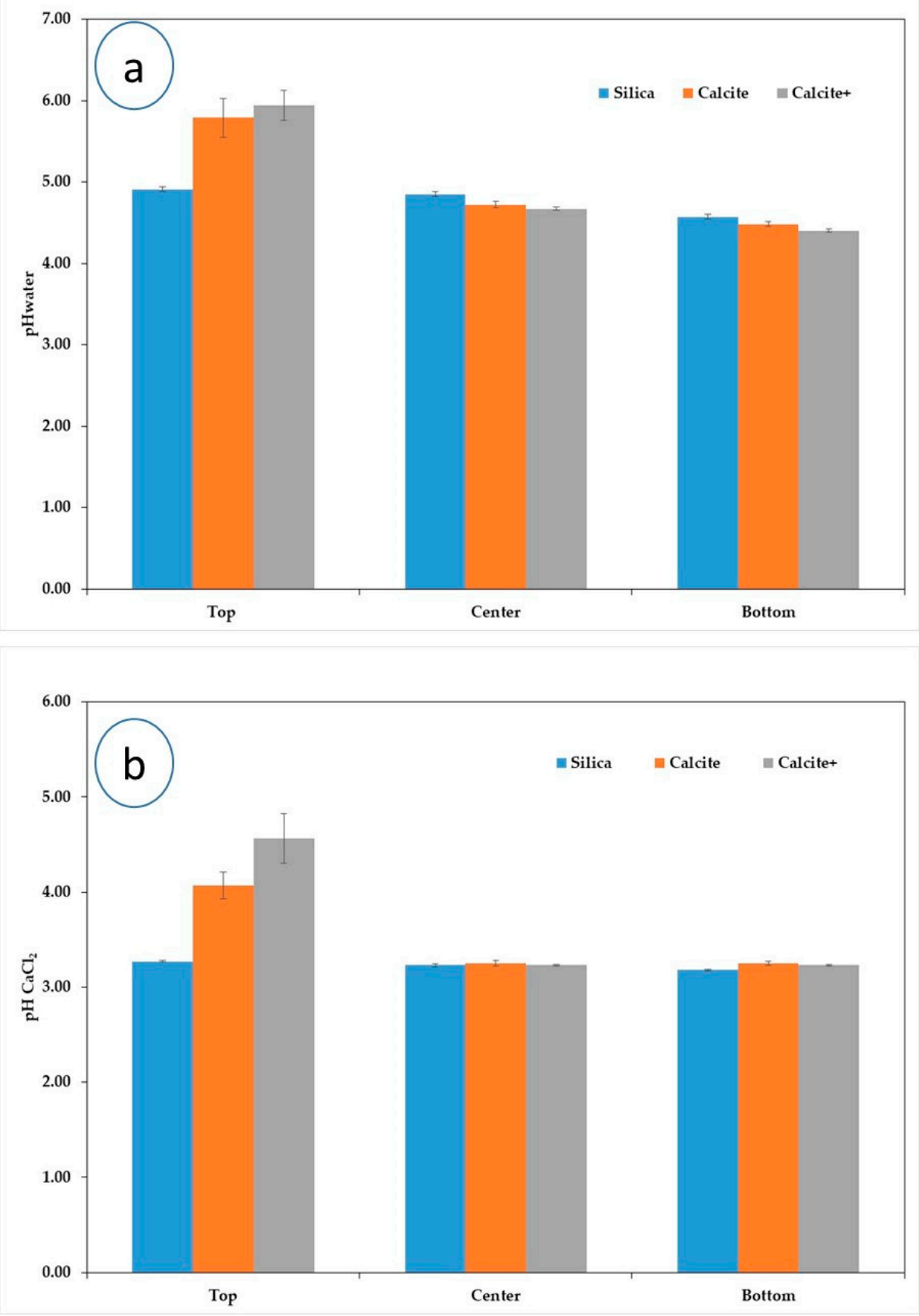

Figure 6. Variation of the gradient of (a) $\mathrm{pH}_{\text {water }}$ and (b) $\mathrm{pHCaCl}_{2}$ of peat substrate during the first growing season (2 June 2014, before fertilization) of white spruce seedlings according to the covering material (silica: $29 \mathrm{~g}$ /cavity, calcite: $24 \mathrm{~g}$ /cavity and calcite+: $31 \mathrm{~g} /$ cavity) and the level of the substrate plug (top, center and bottom). 


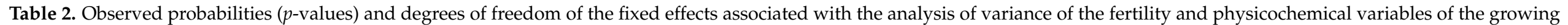
media depending to the covering material (Silica, Calcite and Calcite + ) during the first growing season of white spruce seedlings $(1+0)$.

\begin{tabular}{|c|c|c|c|c|c|c|c|c|c|c|c|c|}
\hline $\begin{array}{l}\text { Source of } \\
\text { Variation }\end{array}$ & $\mathrm{d} \ln *$ & dld * & $\underset{\text { Water }}{\mathrm{pH}}$ & $\underset{\mathrm{CaCl}_{2}}{\mathrm{pH}}$ & $\begin{array}{l}\text { Cond } \\
(\mu \mathrm{S} / \mathrm{cm})\end{array}$ & $\begin{array}{l}\mathrm{N}-\mathrm{NH}_{4} \\
(\mathrm{mg} / \mathrm{kg})\end{array}$ & $\begin{array}{l}\mathrm{N}-\mathrm{NO}_{3} \\
(\mathrm{mg} / \mathrm{kg})\end{array}$ & $\underset{(\mathrm{mg} / \mathrm{kg})}{\mathrm{Nmin}}$ & $\begin{array}{c}\mathrm{P} \\
(\mathrm{mg} / \mathrm{kg})\end{array}$ & $\begin{array}{c}\mathrm{K} \\
(\mathrm{mg} / \mathrm{kg})\end{array}$ & $\begin{array}{c}\mathrm{Ca} \\
(\mathrm{mg} / \mathrm{kg})\end{array}$ & $\underset{(\mathrm{mg} / \mathrm{kg})}{\mathrm{Mg}}$ \\
\hline Treatement & 2 & 17.0 & 0.0004 & 0.0001 & 0.0001 & $<0.0001$ & 0.0025 & 0.0119 & $<0.0001$ & 0.0025 & $<0.0001$ & $<0.0001$ \\
\hline $\begin{array}{l}\text { Calcite/Calcite+ } \\
\text { vs. Silica }\end{array}$ & (1) & 17.0 & 0.0002 & $<0.0001$ & 0.8206 & $<0.0001$ & 0.0079 & 0.0873 & $<0.0001$ & 0.0020 & $<0.0001$ & $<0.0001$ \\
\hline $\begin{array}{l}\text { Calcite vs. } \\
\text { Calcite+ }\end{array}$ & (1) & 17.0 & 0.0669 & 0.2322 & $<0.0001$ & 0.0563 & 0.0132 & 0.0112 & 0.4625 & 0.0767 & 0.0219 & 0.0028 \\
\hline Date & 7 & 16.0 & $<0.0001$ & $<0.0001$ & $<0.0001$ & $<0.0001$ & $<0.0001$ & $<0.0001$ & $<0.0001$ & $<0.0001$ & $<0.0001$ & $<0.0001$ \\
\hline $\begin{array}{l}\text { Date (linear } \\
\text { effect) }\end{array}$ & (1) & 14.6 & $<0.0001$ & $<0.0001$ & $<0.0001$ & $<0.0001$ & $<0.0001$ & $<0.0001$ & $<0.0001$ & $<0.0001$ & $<0.0001$ & $<0.0001$ \\
\hline $\begin{array}{c}\text { Date } \\
\text { (quadratic } \\
\text { effect) }\end{array}$ & (1) & 16.2 & $<0.0001$ & 0.5654 & $<0.0001$ & 0.0003 & $<0.0001$ & $<0.0001$ & $<0.0001$ & $<0.0001$ & $<0.0001$ & $<0.0001$ \\
\hline $\begin{array}{l}\text { Date } \times \\
\text { Treatment }\end{array}$ & 14 & 16.0 & 0.1496 & 0.0262 & 0.0001 & $<0.0001$ & 0.0016 & 0.0053 & $<0.0001$ & 0.0013 & $<0.0001$ & 0.0047 \\
\hline
\end{tabular}

* dln: degrees of freedom of numerator; dld: degrees of freedom of denominator. The dld presented are those for $\mathrm{pH}_{\mathrm{water}}$. They vary from 8.9 and 55.2 for other variables. 
The orthogonal contrasts showed that the mean $\mathrm{pH}_{\mathrm{CaCl} 2}$ and the mean concentration of calcium in the substrate of the two calcite treatments were significantly higher than those of silica treatment for all the sampling dates (Table 2 and Table S2, Figure 7a,b). The mean calcium concentration of the substrate of the two calcite treatments (calcite and calcite+) measured during the different sampling dates was generally almost double of that observed in the substrate covered by silica (Figure 7a). No significant difference was observed between the $\mathrm{pH}_{\mathrm{CaCl} 2}$ of the two calcite-based treatments (Table S2).

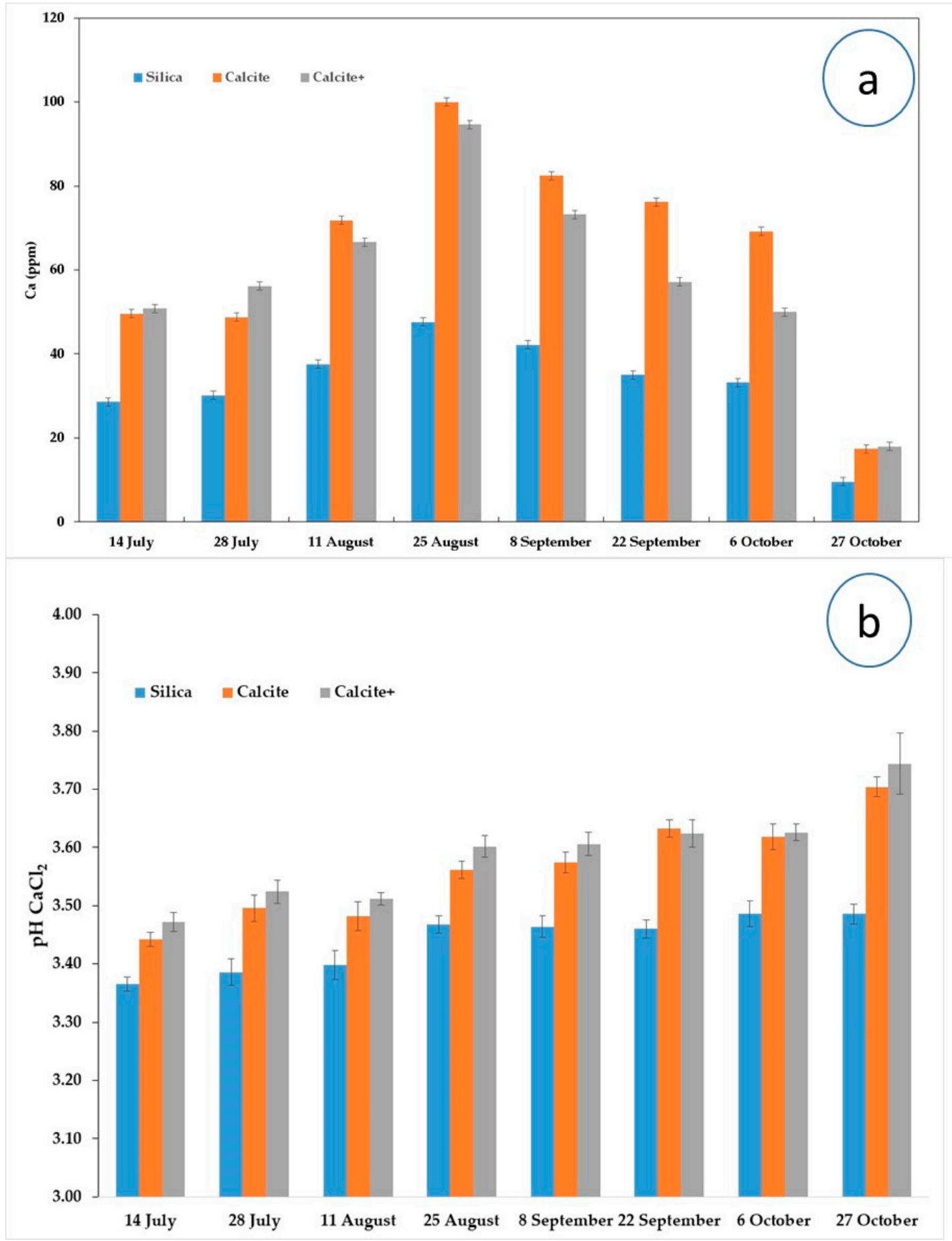

Figure 7. Variations in (a) the calcium concentration, and (b) the $\mathrm{pHCaCl}_{2}$ of the growing peat media during the first growing season of white spruce seedlings $(1+0)$ depending on the cover material (silica: $29 \mathrm{~g} /$ cavity, calcite: $24 \mathrm{~g} /$ cavity and calcite+: $31 \mathrm{~g} /$ cavity). 
At the last sampling (27 October 2014), despite the addition of calcite at two doses (calcite and calcite+), there was no significant difference between the mean electrical conductivity of the substrate of the two calcite treatments (calcite and calcite+) and that of silica (Table S2). Although a significant difference between the calcite treatments and that of silica treatments during two of the sampling dates concerning the electrical conductivity (Table S2), electrical conductivity did not exceed $257.4 \mu \mathrm{S} / \mathrm{cm}$ throughout the growing season.

The $\mathrm{pH}_{\mathrm{CaCl}}$ is significantly correlated with the calcium fertility of the growing substrate $(r=0.62, p<0.0001)$ using data from the first seven sampling dates between 14 July and 6 October 2014.

\subsection{Growth of White Spruce Seedlings $(1+0)$}

The interaction between date and treatment was significant for all growth variables (Table 3). At the end of the growing season (27 October 2014), the two calcite-based treatments did not differ significantly for all the growth variables (height $(\mathrm{H})$, diameter $(\mathrm{D})$, $\mathrm{H} / \mathrm{D}$, shoot dry mass, root dry mass and total dry mass) (Table S3). The mean of the two calcite-based treatments for the different growth variables was significantly higher than that of silica treatments. At the end of the first growing season, the two Calcite treatments (Calcite and Calcite+) significantly increased the total dry mass $(28 \%)$, roots $(27 \%)$ and shoot $(29 \%)$ dry masses and height $(24 \%)$ compared to Silica treatment (Table 3 ).

\subsection{Determination of Logistic Growth Models According to the Covering Material}

During the growing season, the variation of the growth attributes (height, diameter, shoot and roots dry masses, and total dry mass) was adjusted with logistic models (Figure 8) whose parameters (a: asymptote, b: inflection point and c: growth rate) differ significantly depending on the recovery treatment (Table S4). The coefficients of determination $\left(R^{2}\right)$ varied from 0.70 to 0.96 (Figure 8). The estimates of the parameters of the various logistic models, as well as the confidence interval of the values predicted by the models are shown in Table $\mathrm{S} 4$ and Figure 8. Comparisons of the asymptotes of the logistic models clearly show that the calcite material significantly increased all growth variables of the white spruce seedlings $(1+0)$ compared to those of the silica cover (Figure 8).

\subsection{Dry Matter Allocation Models between the Shoots and the Roots According to the Covering Material}

The parameter estimates of the logistic models of allocation of the dry matter between the shoots and the roots of white spruce seedlings $(1+0)$ are shown in Table 4 . Parameters of the models for the two calcite-based treatments did not differ significantly while parameters of the allocation model associated with Silica treatments differ significantly from those of the two calcite treatments combined. The cover material changed the allocation of dry matter or carbon, throughout the growing season, between the shoots and roots of white spruce seedlings $(1+0)$. 


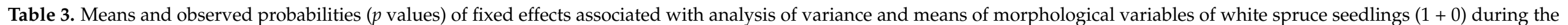
first growing season.

\begin{tabular}{|c|c|c|c|c|c|c|c|c|}
\hline $\begin{array}{l}\text { Source of } \\
\text { Variation }\end{array}$ & $\mathrm{dln} *$ & dld * & $\begin{array}{l}\text { Height (H) } \\
\text { (cm) }\end{array}$ & $\begin{array}{l}\text { Diameter (D) } \\
(\mathrm{mm})\end{array}$ & H/D & $\begin{array}{c}\text { Shoot Dry Mass } \\
(\mathrm{mg})\end{array}$ & $\begin{array}{c}\text { Root Dry Mass } \\
(\mathrm{mg})\end{array}$ & $\begin{array}{c}\text { Total Dry Mass } \\
\text { (g) }\end{array}$ \\
\hline Treatment & 2 & 26.0 & $<0.0001$ & $<0.0001$ & $<0.0001$ & 0.0001 & $<0.0001$ & $<0.0001$ \\
\hline $\begin{array}{c}\text { Calcite/calcite+ vs. } \\
\text { Silica }\end{array}$ & (1) & 26.0 & $<0.0001$ & $<0.0001$ & $<0.0001$ & $<0.0001$ & $<0.0001$ & $<0.0001$ \\
\hline $\begin{array}{l}\text { Calcite vs. } \\
\text { Calcite+ }\end{array}$ & (1) & 26.0 & 0.0232 & 0.0302 & 0.2198 & 0.0993 & 0.0628 & 0.0819 \\
\hline Date & 7 & 22.5 & $<0.0001$ & $<0.0001$ & $<0.0001$ & $<0.0001$ & $<0.0001$ & $<0.0001$ \\
\hline Date (linear effect) & $(1)$ & 21.3 & $<0.0001$ & $<0.0001$ & $<0.0001$ & $<0.0001$ & $<0.0001$ & $<0.0001$ \\
\hline Date $\times$ Treatment & 14 & 22.5 & $<0.0001$ & 0.0001 & 0.0486 & 0.0041 & $<0.0001$ & 0.0011 \\
\hline \multicolumn{9}{|c|}{ Means ( $n=75$, error standard) of different morphological variables at the end of the first growing season (27 October 2014) } \\
\hline Calcite & & & $9.0 \pm 0.17$ & $2.3 \pm 0.04$ & $4.66 \pm 015$ & $836.9 \pm 29.4$ & $528.1 \pm 14.3$ & $1.36 \pm 0.04$ \\
\hline Calcite+ & & & $9.5 \pm 0.17$ & $2.3 \pm 0.04$ & $4.70 \pm 0.15$ & $889.5 \pm 29.4$ & $561.6 \pm 14.3$ & $1.45 \pm 0.04$ \\
\hline Silica & & & $7.5 \pm 0.17$ & $2.1 \pm 0.04$ & $3.89 \pm 0.15$ & $669.8 \pm 29.4$ & $427.1 \pm 14.3$ & $1.09 \pm 0.04$ \\
\hline
\end{tabular}

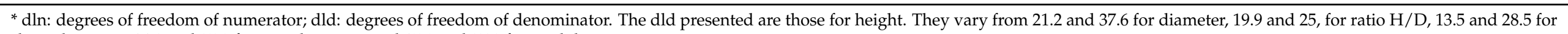
shoot dry mass, 14.8 and 25.2 for root dry mass, and 15.0 and 27.8 for total dry mass. 

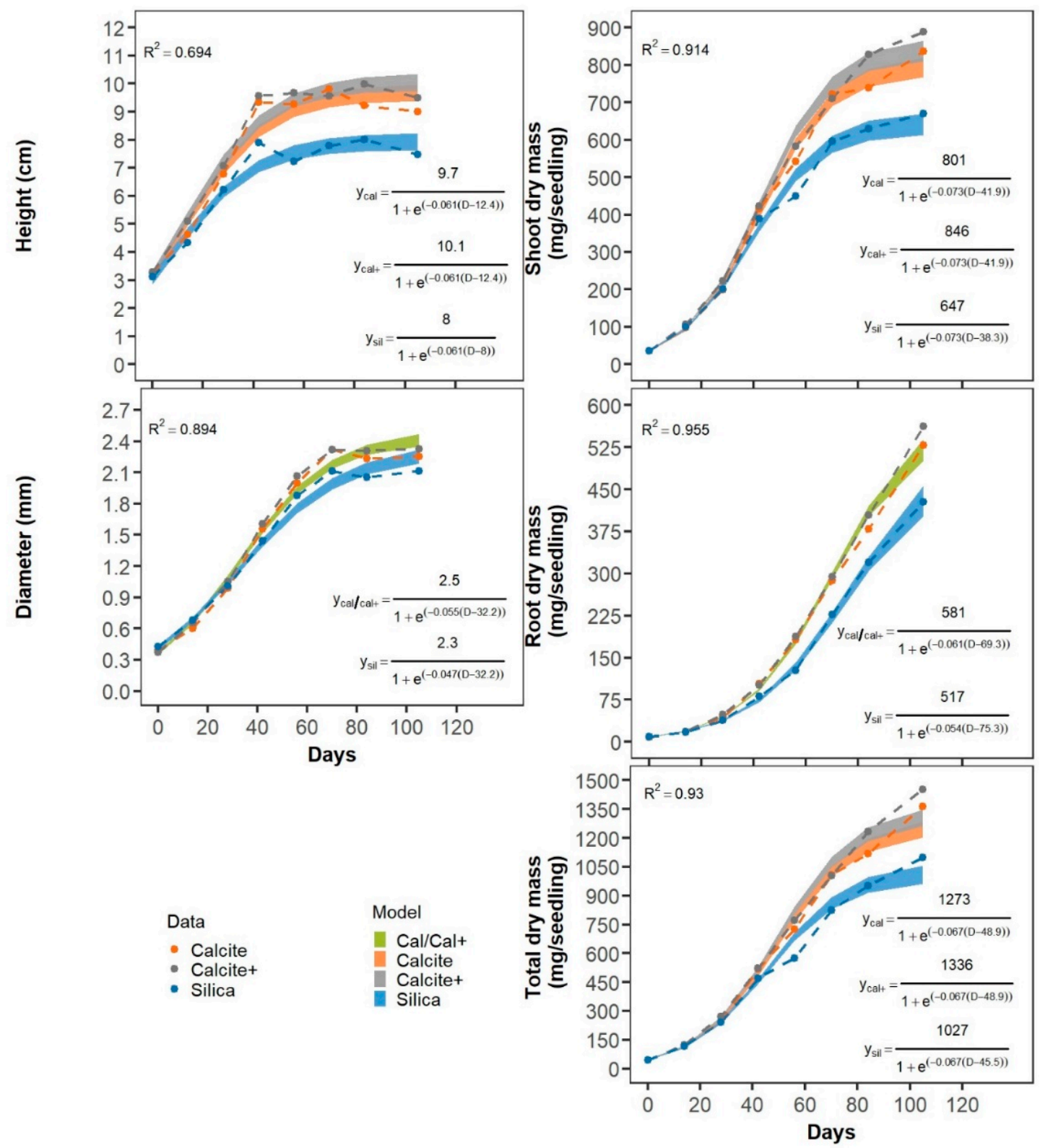

Figure 8. Evolution of the means and logistic models adjusted for each of the growth variables of white spruce seedlings $(1+0)$, depending on the treatments (silica, calcite and calcite+). The width of each band corresponds to the $95 \%$ confidence interval. As the parameters of the calcite and calcite+ treatments did not differ significantly from each other, a single logistic model was generated by combining the data from these two treatments. The models were adjusted using all the data ( $n=600$ seedlings/treatment for height and diameter, and $n=200$ composite samples of three seedlings/treatment for shoot, roots and total dry masses. 
Table 4. Estimation of the parameters of the dry mass allocation model between the shoots and the roots of white spruce seedlings $(1+0)$ depending to the cover treatments.

\begin{tabular}{cccccc}
\hline Parameter & Estimate & Standard Error & $p$ Value & $\begin{array}{c}\text { Lower Bound of a } \\
\text { Confidence Interval 95\% }\end{array}$ & $\begin{array}{c}\text { Upper Bound of a } \\
\text { Confidence Interval IC 95\% }\end{array}$ \\
\hline a0 & 6.8011 & 0.0790 & $<0.0001$ & 6.6447 & 6.9575 \\
a12 & 0.4567 & 0.1059 & $<0.0001$ & 0.2470 & 0.6664 \\
b0 & 1.9991 & 0.0318 & $<0.0001$ & 1.9362 & 2.0620 \\
b12 & 0.1320 & 0.0452 & 0.0042 & 0.0425 & 0.2215 \\
c0 & 0.7787 & 0.0427 & $<0.0001$ & 0.6942 & 0.8632 \\
c12 & -0.1498 & 0.0461 & 0.0015 & -0.2411 & -0.0585 \\
\hline
\end{tabular}

Compared to the silica covering and for the same shoot dry mass, the calcite material increased the dry matter allocated to root by $23.8 \%$. At the end of the growing season, the calcite covering significantly improved the growth of roots and shoots (Figure 9, Table 3).
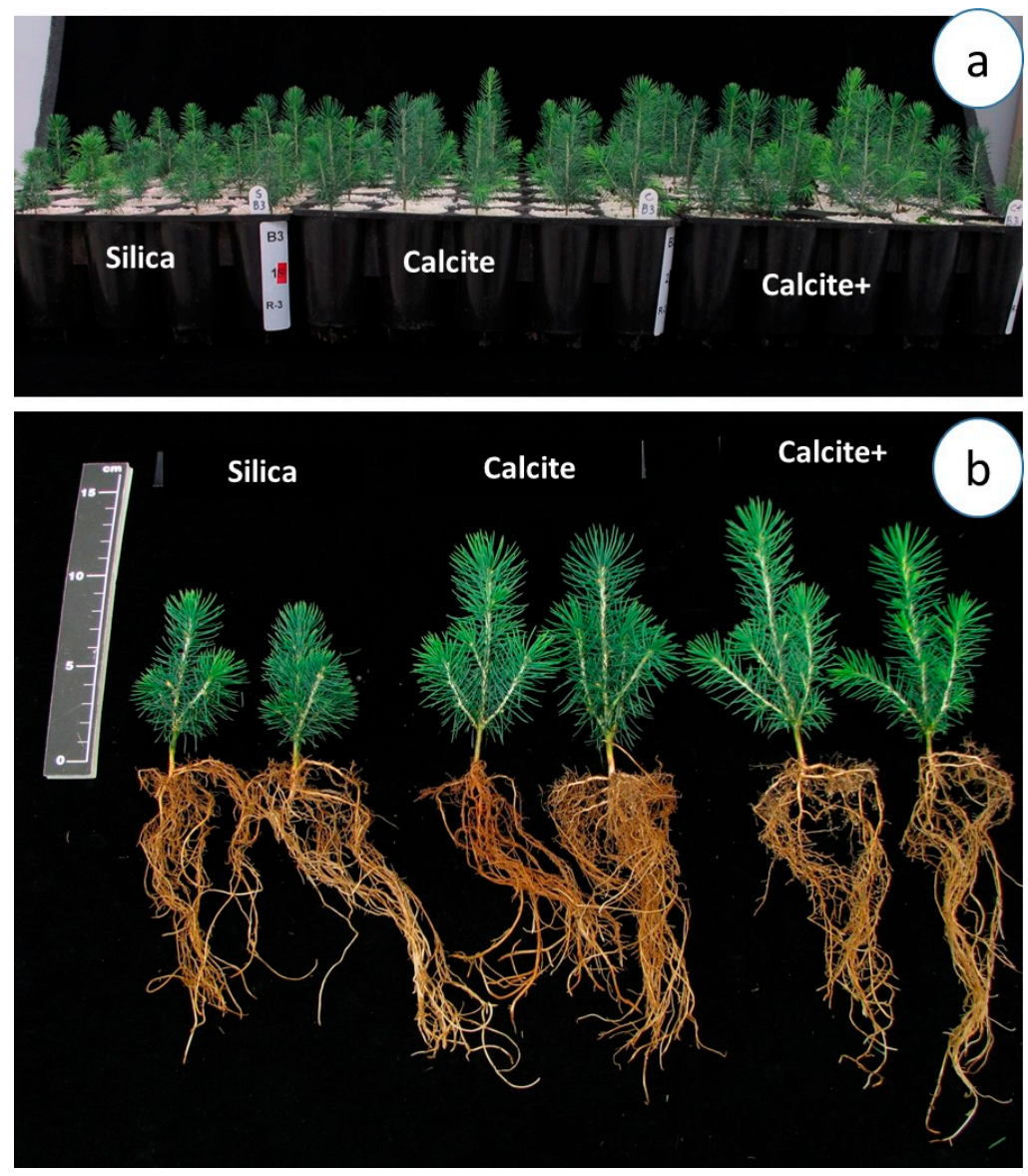

Figure 9. (a) Example of growth of white spruce seedlings $(1+0)$ depending to the covering material (silica: $29 \mathrm{~g}$ /cavity, calcite: $24 \mathrm{~g}$ /cavity and calcite+: $31 \mathrm{~g} /$ cavity) (Photo: 8 September 2014); (b) Phenotypic aspects of roots and shoots of white spruce seedlings $(1+0)$ depending on the covering material (Photo: 22 September 2014).

\subsection{Mineral Nutrition}

The interaction between the date and the treatment was significant for the contents, the concentrations and the mineral nutrient use efficiencies for all the variables of mineral nutrition, except for shoot $\mathrm{Mg}$ content (Table 5), the concentration and phosphorus use efficiency (PUE), as well as the Mg content of the roots (Table 6). The use of calcite as a covering material did not cause any visible deficiency of all the mineral nutrients. 


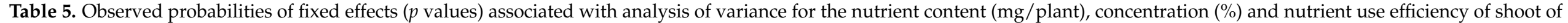
white spruce seedlings $(1+0)$.

\begin{tabular}{|c|c|c|c|c|c|c|c|c|c|c|c|c|c|c|c|}
\hline Source of Variation & $\mathrm{d} \ln *$ & dld * & $\begin{array}{c}\mathrm{N} \\
(\mathrm{mg} / \mathrm{plt})\end{array}$ & $\begin{array}{c}\mathbf{P} \\
(\mathrm{mg} / \mathrm{plt})\end{array}$ & $\begin{array}{c}\mathrm{K} \\
(\mathrm{mg} / \mathrm{plt})\end{array}$ & $\begin{array}{c}\mathrm{Ca} \\
(\mathrm{g} / \mathrm{plt})\end{array}$ & $\underset{\text { (mg/plt) }}{\mathrm{Mg}}$ & $\begin{array}{c}N \\
(\%)\end{array}$ & $\begin{array}{c}P \\
(\%)\end{array}$ & $\begin{array}{c}K \\
(\%)\end{array}$ & $\begin{array}{l}\mathrm{Ca} \\
(\%)\end{array}$ & $\begin{array}{l}\mathrm{Mg} \\
(\%)\end{array}$ & NUE * & PUE * & KUE* \\
\hline Treatement & 2 & 16.8 & 0.0003 & $<0.0001$ & 0.0791 & $<0.0001$ & 0.0391 & 0.0018 & 0.5371 & 0.8526 & $<0.0001$ & $<0.0001$ & 0.0068 & 0.2907 & 0.2346 \\
\hline Calcite/Calcite+ vs. Silica & $(1)$ & 16.8 & 0.0001 & $<0.0001$ & 0.0442 & $<0.0001$ & 0.0176 & 0.0005 & 0.2734 & 0.8964 & $<0.0001$ & $<0.0001$ & 0.0021 & 0.1325 & 0.0969 \\
\hline Date & 7 & 15.5 & $<0.0001$ & $<0.0001$ & $<0.0001$ & $<0.0001$ & $<0.0001$ & $<0.0001$ & $<0.0001$ & $<0.0001$ & $<0.0001$ & $<0.0001$ & $<0.0001$ & $<0.0001$ & $<0.0001$ \\
\hline Date (linear effect) & $(1)$ & 17.1 & $<0.0001$ & $<0.0001$ & $<0.0001$ & $<0.0001$ & $<0.0001$ & $<0.0001$ & $<0.0001$ & $<0.0001$ & $<0.0001$ & $<0.0001$ & $<0.0001$ & $<0.0001$ & $<0.0001$ \\
\hline Date (quadratic effect) & (1) & 37.9 & $<0.0001$ & 0.2192 & $<0.0001$ & 0.0111 & $<0.0001$ & $<0.0001$ & $<0.0001$ & $<0.0001$ & 0.0150 & 0.1715 & $<0.0001$ & $<0.0001$ & $<0.0001$ \\
\hline Date $\times$ Treatment & 14 & 15.5 & 0.0044 & 0.0025 & 0.0021 & $<0.0001$ & 0.0738 & 0.0005 & 0.0005 & $<0.0001$ & $<0.0001$ & $<0.0001$ & 0.0008 & 0.0045 & $<0.0001$ \\
\hline
\end{tabular}

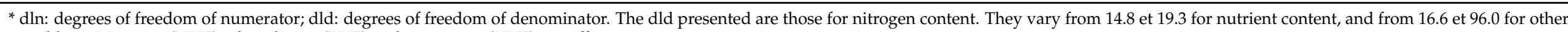
variables. * Nitrogen (NUE), phosphorus (PUE) and potassium (KUE) use efficiency.

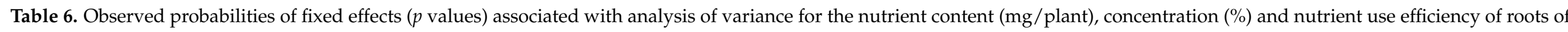
white spruce seedlings $(1+0)$.

\begin{tabular}{|c|c|c|c|c|c|c|c|c|c|c|c|c|c|c|c|}
\hline Source of Variation & $\operatorname{dln} *$ & dld * & $\begin{array}{c}\mathrm{N} \\
\text { (mg/plt) }\end{array}$ & $\begin{array}{c}\mathbf{P} \\
\text { (mg/plt) }\end{array}$ & $\begin{array}{c}\mathrm{K} \\
\text { (mg/plt) }\end{array}$ & $\begin{array}{c}\text { Ca } \\
\text { (mg/plt) }\end{array}$ & $\underset{\text { (mg/plt) }}{\mathrm{Mg}}$ & $\begin{array}{c}N \\
(\%)\end{array}$ & $\begin{array}{c}P \\
(\%)\end{array}$ & $\begin{array}{c}K \\
(\%)\end{array}$ & $\begin{array}{l}\mathrm{Ca} \\
(\%)\end{array}$ & $\begin{array}{l}\mathrm{Mg} \\
(\%)\end{array}$ & NUE * & PUE * & KUE * \\
\hline Treatment & 2 & 20.9 & 0.0001 & $<0.0001$ & $<0.0001$ & $<0.0001$ & 0.0020 & 0.0001 & 0.1945 & $<0.0001$ & $<0.0001$ & 0.0722 & $<0.0001$ & 0.1681 & $<0.0001$ \\
\hline Calcite/Calcite+ vs. Silica & $(1)$ & 20.9 & $<0.0001$ & $<0.0001$ & $<0.0001$ & $<0.0001$ & 0.0005 & $<0.0001$ & 0.4100 & $<0.0001$ & $<0.0001$ & 0.0358 & $<0.0001$ & 0.2701 & $<0.0001$ \\
\hline Calcite vs. Calcite+ & (1) & 20.9 & 0.7540 & 0.3541 & 0.7315 & 0.0025 & 0.8102 & 0.0100 & 0.1070 & 0.0053 & 0.1740 & 0.3284 & 0.0070 & 0.1228 & 0.0267 \\
\hline Date & 5 & 21.6 & $<0.0001$ & $<0.0001$ & $<0.0001$ & $<0.0001$ & $<0.0001$ & $<0.0001$ & $<0.0001$ & $<0.0001$ & $<0.0001$ & $<0.0001$ & $<0.0001$ & $<0.0001$ & $<0.0001$ \\
\hline Date (linear effect) & (1) & 17.5 & $<0.0001$ & $<0.0001$ & $<0.0001$ & $<0.0001$ & $<0.0001$ & $<0.0001$ & 0.2273 & $<0.0001$ & $<0.0001$ & $<0.0001$ & $<0.0001$ & 0.1343 & $<0.0001$ \\
\hline Date (quadratic effect) & (1) & 34.4 & 0.0006 & 0.3812 & $<0.0001$ & 0.0864 & $<0.0001$ & $<0.0001$ & 0.0001 & $<0.0001$ & 0.0001 & $<0.0001$ & $<0.0001$ & 0.0002 & $<0.0001$ \\
\hline Date $\times$ Treatment & 10 & 21.6 & 0.0302 & $<0.0001$ & 0.0001 & $<0.0001$ & 0.2866 & 0.0327 & 0.1919 & $<0.0001$ & $<0.0001$ & 0.0013 & 0.0189 & 0.1697 & 0.0001 \\
\hline
\end{tabular}

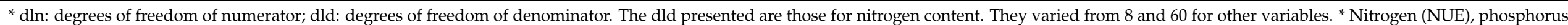

(PUE) and potassium (KUE) use efficiency. 
The date effect was significant for all mineral nutrient variables (content, concentration and use efficiency of mineral nutrients) of the roots and shoots (Tables 5 and 6). The linear and quadratic effects of the date were significant for several variables (concentrations and contents) of the mineral nutrients in roots and shoots (Tables 5 and 6 with the exception of $\mathrm{K}$ content and concentration, $\mathrm{P}$ concentration, and use efficiency of $\mathrm{P}$ and $\mathrm{K}$, the treatment effects were significant for all other nutrient variables (content, concentration and use efficiency of mineral nutrients) of the shoots (Table 5). For roots, the treatment effect was not significant for $\mathrm{P}$ and $\mathrm{Mg}$ concentrations and P use efficiency (PUE) (Table 6).

For Ca content and concentration in shoots, the orthogonal contrasts showed the absence of a significant difference between the two calcite-based treatments at all practically the sampling dates (Table S5). On the other hand, Ca concentration and content means of the two Calcite treatments were significantly higher than that of Silica treatments (Table S5, Figure 10a,b). This trend was maintained during the different sampling dates (Table S5, Figure 10a,b).

For N, no significant difference was observed between the mean concentrations and stem contents of the two calcite treatments throughout the growing season (Table S5, Figure 11a,b). However, at the last sampling date, a difference was observed between the mean nitrogen concentrations of the shoots of the two calcite treatments and that of the Silica treatments (Table S5). For N content in shoots, difference between treatments was observed during three sampling dates (Table S5) without affect growth or inducing visible symptoms of deficiency in the needles (Figure 9). In fact, $\mathrm{N}$ concentrations in the shoots remained relatively high throughout the first growing season for all treatments (Figure 11a) and ranged between $2.24 \%$ and $2.83 \%$ (Figure 11 a) for the calcite treatments.

For the use efficiency of the three mineral nutrients $(\mathrm{N}, \mathrm{P}$ and $\mathrm{K}$ ) of shoots and roots, the orthogonal contrasts showed the presence of differences associated with certain sampling dates (Tables S5 and S6). For example, at the last sampling date, the average $\mathrm{N}$ use efficiency (NUE) of the shoots of the two calcite treatments (calcite+: $44.74 \pm 0.75$; calcite: $44.09 \pm 0.75)$ was significantly higher than that of silica treatments $(39.66 \pm 0.75)$ (Table S5). 

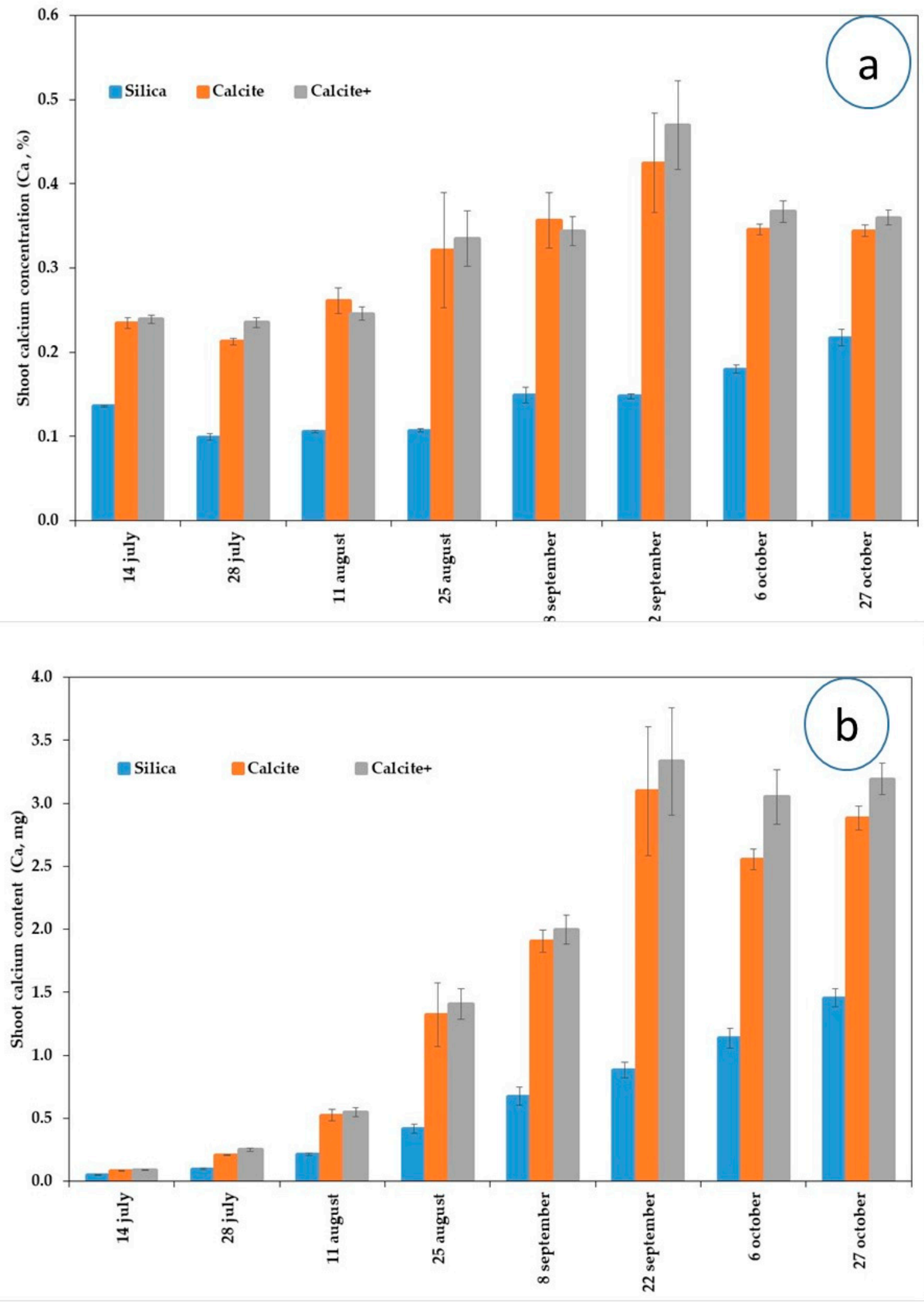

Figure 10. Variations (a) in the calcium concentration (Ca, \%), and (b) in the calcium content (Ca, mg) in the shoots during the first growing season of white spruce seedling $(1+0)$ depending on the covering material (silica: 29 g/cavity, calcite: $24 \mathrm{~g} /$ cavity and calcite+: $31 \mathrm{~g} /$ cavity). 

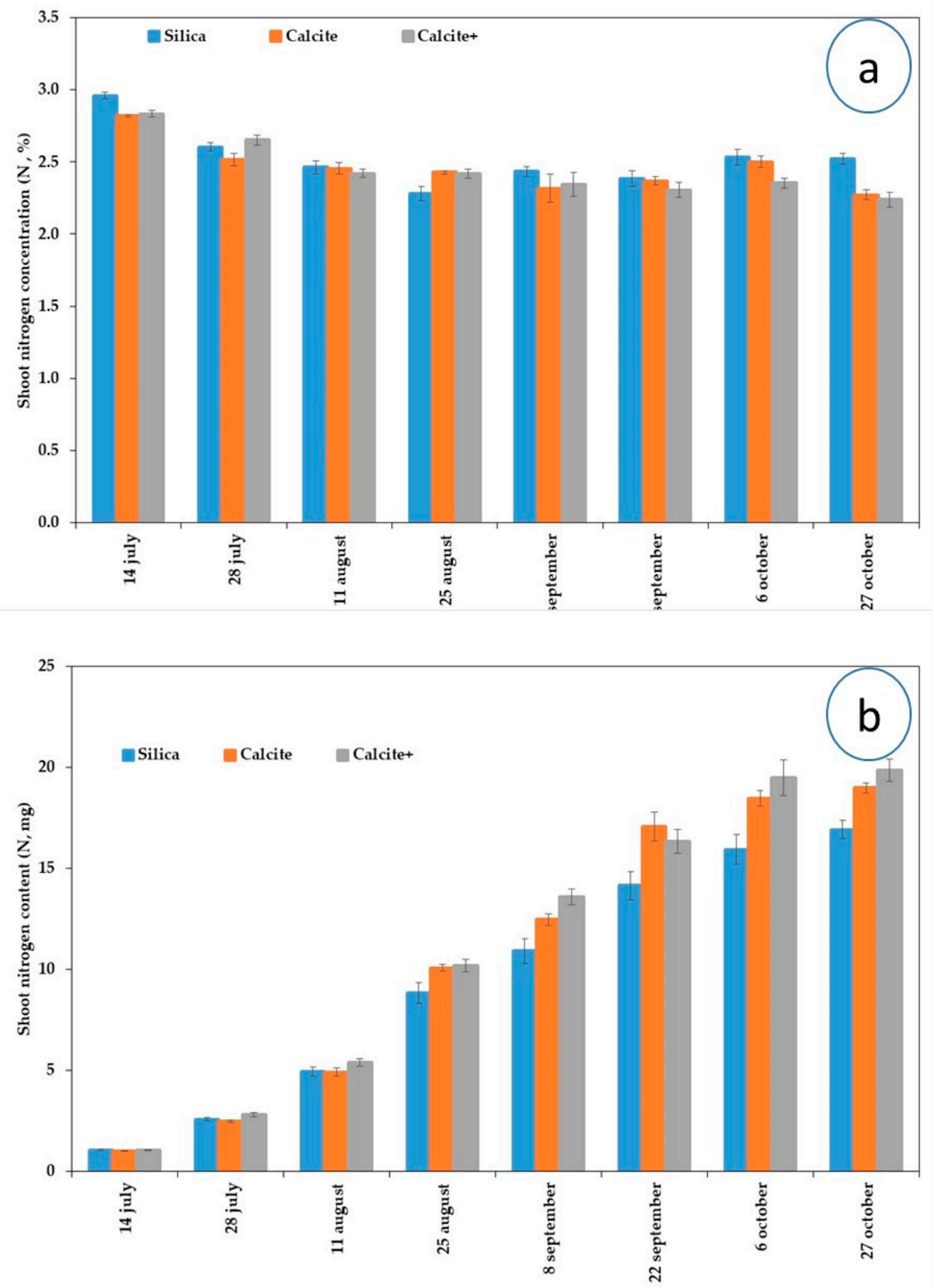

Figure 11. Variations (a) in the nitrogen concentration $(\mathrm{N}, \%)$, and $(\mathbf{b})$ in the nitrogen content $(\mathrm{N}, \mathrm{mg})$ in the shoots during the first growing season of white spruce seedling $(1+0)$ depending on the covering material (silica: $29 \mathrm{~g} /$ cavity, calcite: $24 \mathrm{~g} /$ cavity and calcite+: $31 \mathrm{~g} /$ cavity). 


\section{Discussion}

The replacement of silica, as a covering material, by calcite significantly increased all the growth variables of white spruce seedlings $(1+0)$ and improved different chemical properties of the substrate $(\mathrm{pH}$, fertility of the substrate in calcium, etc.) under forest nursery conditions. For example, at the end of the first growing season, the two calcite treatments significantly increased the total dry mass $(28 \%)$, roots $(27 \%)$ and shoot $(29 \%)$ dry masses and height $(24 \%)$ compared to silica treatments. Achieving certain growth targets, including a seedling height of $9-10 \mathrm{~cm}$ and increasing growth variables during the first growing season $(1+0)$ are among the goals of nursery managers and are easily achieved through the use of calcite as a covering material (Figure 8) provided that the other crop management parameters (irrigation, fertilization, etc.) are optimal. Our recent results [20] have shown that the use of calcite did not affect seed germination rate or cavity occupancy rate (Figure 9). The mean occupancy rate of the cavities was similar between the three treatments, i.e., $99.33 \%$ [20]. Also, the use of calcite did not promote the development of mosses and algae (Figure 9a) and did not affect the temperature at the substrate-covering material interface (Figure 2) which remained generally optimal for white spruce seed germination [29].

The improvement in the $\mathrm{pH}$ gradient after seed germination (Figure 6) and during the growing season (Figure 7) generated by calcite was generally optimal ( $\mathrm{pH}$ water between 4 and 5) for the growth and mineral nutrition of boreal tree species produced in peaty substrates [16]. Indeed, the release of calcium from calcite in the soil solution contributed to the significant increase in the fertility of the calcium substrate compared to that of silica (Figure 7a). Thus, a positive correlation was observed between the fertility of the calcium substrate and the increase in $\mathrm{pH}$. Therefore, the concentration of calcium and the amount of calcium absorbed, for example, in the shoots and roots of white spruce seedlings $(1+0)$ were significantly higher than those of seedlings covered with silica (Figure 10). The addition of calcite as a covering material generated an adequate electrical conductivity for seedling growth $(257.4 \mu \mathrm{S} / \mathrm{cm})$ because it is relatively very low compared to the critical salinity $(>2500 \mu \mathrm{S} / \mathrm{cm}$ ) which significantly reduces seedling growth of some boreal tree species [30].

The increased growth (Figures 8 and 9) could be partly due to the large amount of $\mathrm{Ca}$ absorbed by white spruce seedlings $(1+0)$ (Figure 10b) because this nutrient is involved in different physiological processes. Calcium activates cell division and elongation, regulates cell membrane permeability, strengthens cell wall stiffness, and acts as a regulator of photosynthesis in synergy with abscisic acid during stomata opening [31-33]. Calcium also stimulates photosynthesis and the absorption of nitrogen, phosphorus and potassium [34,35]. For example, nitrogen concentrations of white spruce seedlings varied between $2.24 \%$ and $2.83 \%$ (Figure 11a) for calcite treatments. These concentrations greatly exceed the standard of the foliar nitrogen concentration $(\geq 1.6 \%)$ required for large white spruce seedlings before their delivery to a reforestation site [9]. Gagnon and Lamhamedi [36] have shown that leaf nitrogen concentrations greater than $1.7 \%$ significantly improve the morphophysiological performance of seedlings during their installation phase in a reforestation site. Under controlled conditions for two years, simulating reforestation conditions, our results [36] also showed that the growth of roots and net photosynthesis of large white spruce $(2+0)$ seedlings are positively correlated with leaf nitrogen concentration. When the leaf nitrogen concentration is less than $1.5 \%$, the rate of net photosynthesis and root dry mass are very weak.

For other vascular plants, calcium improves the absorption of trace elements, including iron, manganese, zinc and boron [37]. Improving the nutritional status of seedlings with calcium also directly contributes to improving the resistance of vascular plants to flooding [35], high temperatures [38] and other environmental stresses (frost, salinity, etc.) [39-41]. Therefore, improving root plug cohesion and plant tolerance to environmental stress could decrease the number of seedlings rejected due to insufficient root development [42-44] and improve the profitability of forest nurseries. Our recent study has 
shown that the use of calcite stimulated early colonization of the roots of white spruce by ectomycorrhizal fungi and the development of the extramatrical phase [20]. The presence of these fungi improves the root-plug cohesion and the soil structure [20,45-47], as well as the performance of tree seedlings on reforestation sites [48-51]. In addition, ectomycorrhizal fungi improve plant resistance to pathogenic fungi [52-54], frost [55] and drought stress [56-59].

The maximum values (e.g., asymptotes) associated with the different growth variables generated by the logistic models also showed the advantage of the two calcite treatments (calcite and calcite+) over the silica treatments (Figure 8, Table S4). These growth models can be used by nursery managers as growth standards for regular monitoring of white spruce crops in order to optimize the various cultural practices (irrigation, fertilization, etc.) and meet morphophysiological quality standards of seedlings for reforestation.

\section{Conclusions and Practical Recommendations}

The use of calcite as a covering material has significantly improved various physicochemical properties of the substrate ( $\mathrm{pH}$, calcium fertility, etc.), growth variables and mineral nutrition of white spruce seedlings during the first growing season under forest nursery conditions. To our knowledge, this is the first assessment of the effects of granular calcite used as covering material on substrate physicochemistry (e.g., micro vertical changes in $\mathrm{pH}$ across root-plug, etc.), growth kinetics of roots and shoot and mineral nutrition of forest seedlings produced at an operational scale during the first growing season.

The differences observed between the treatments (micro-vertical changes in substrate $\mathrm{pH}$ and calcium concentration in the root plug) at the end of the germination phase offer an advantage to the seedlings and are certainly at the origin of the increases observed in favor of calcite-based treatments concerning the various variables evaluated (physico-chemistry of the substrate, growth, mineral nutrition). Thus, the $\mathrm{pH}$ gradient observed across vertical root-plugs generated by the use of calcite is within the optimal growth interval of seedlings of boreal tree species produced in peaty substrates [16]. Improving the $\mathrm{pH}$ of the growing medium with calcite should improve absorption and use efficiency of mineral nutrients. The significant and gradual increase in root growth (Table 3, Figure 8) generated by the two calcite treatments certainly increased the absorption capacity of mineral elements by the roots due to the rapid increase in their occupation of cavity space. However, the particle size of calcite should be large enough to avoid the presence of dust, as well as rapid release and migration of calcium into the rhizosphere. The diameter of the calcite particles could vary between 1.2 and $3.2 \mathrm{~mm}$. The amount of calcite should not exceed the ratio of $31 \mathrm{~g} / 310 \mathrm{~cm}^{3}$ cavity. For other containers, the nursery managers should readjust this ratio according to the volume of the cavity. Our recent study [21] has shown that the proportion of the fine class $(<1 \mathrm{~mm})$ of calcite should not exceed $17 \%$.

Increasing the concentration and calcium content of the shoots through the use of calcite will help improve the seedlings' tolerance to fall frost [60]. Thus, the nursery manager could significantly reduce or even eliminate the need to fertilize seedlings with calcium nitrate $\mathrm{CaNO}_{3}$ in the fall to improve hardening and seedling tolerance to fall frost. The use of calcite as a covering material will eliminate the need for inputs to increase the $\mathrm{pH}$ of peat substrates or the purchase of a more expensive peat substrate with readjusted $\mathrm{pH}$.

The logistic models developed for each of the growth variables of white spruce seedlings $(1+0)$ could be used by nursery managers as growth standards in order to optimize the various culture management systems and reach the growth targets at the end of the first growing season in a forest nursery. These growth standards specific to silica and calcite treatments can be integrated into the Plantec software [23] to further optimize crop management in forest nurseries.

Supplementary Materials: The following are available online at https: / www.mdpi.com/article / $10.3390 /$ land10070661/s1. Table S1. Observed probabilities of the contrasts associated with the interactions of the analysis of variance of the variables related to the variations in the $\mathrm{pH}$ gradient and the fertility of the substrate according to the covering material (Silica, Calcite and Calcite+) and 
the height level of the plug- substrate (top, center and bottom) during the germination phase of white spruce seedlings $(1+0)$. Table S2. Observed probabilities of the contrasts of the Date $\times$ interaction of the analysis of variance of the fertility and physico-chemical variables of the substrate during the first growing season of white spruce plants $(1+0)$. Table S3. Observed probabilities of the contrasts of the interaction Date $\times$ Treatment of the analysis of variance of morphological variables during the first growing season of white spruce seedlings $(1+0)$. Table S4. Estimation of the parameters of the logistic model for height, diameter, root and shoot dry masses, and total dry mass of white spruce seedlings $(1+0)$. Table S5. Observed probabilities of the contrasts of the interaction Date $\times$ Treatment of analysis of variance for content ( $\mathrm{mg} / \mathrm{plant})$, concentration (\%) and use efficiency of mineral nutrients in shoots of white spruce seedlings $(1+0)$. Table S6. Observed probabilities of the contrasts of the interaction Date $\times$ Treatment of analysis of variance for content $(\mathrm{mg} / \mathrm{plant})$, concentration (\%) and use efficiency of mineral nutrients in roots of white spruce seedlings $(1+0)$.

Author Contributions: Conceptualization, M.S.L. and M.R.; methodology, M.S.L., M.R. and I.A.; supervision, M.R. and M.S.L.; project administration, M.R. and M.S.L.; statistical analyses, I.A. and M.S.L.; data curation, M.S.L., M.R. and I.A.; writing-original draft preparation, M.S.L.; writingreview and editing, M.S.L., M.R. and I.A. All authors have read and agreed to the published version of the manuscript.

Funding: Funding for this research project was provided by the Direction de la recherche forestière (DRF) of the Ministry of Forests, Wildlife and Parks of the Government of Quebec as part of project no. 3321142332093: Optimization of the cultural practices affecting root insufficiency and the morphophysiological quality of the seedlings produced in forest nurseries (holder: Mohammed S. Lamhamedi).

Institutional Review Board Statement: Not applicable.

Informed Consent Statement: Not applicable.

Acknowledgments: We sincerely thank Chantal Pelletier, Sylvie Goulet and all the staff of the Grandes-Piles nursery for their exceptional technical assistance during all phases of this project. We thank all the staff of the organic and inorganic chemistry laboratory of the Direction de la recherche forestière (DRF) for the mineral analyses of the samples and the enriching discussions with the chemical managers (Carol DeBlois and Denis Langlois). We thank Raed Elferjani, Debra Stowe and Marie-Claude Lambert (Statistician senior, DRF) for their suggestions, the English editing and editorial comments. We thank the staff of the edition and the four reviewers for their valuable comments and suggestions that improved our manuscript considerably.

Conflicts of Interest: The authors declare no conflict of interest. The funders had no role in the design of the study; in the collection, analyses, or interpretation of data; in the writing of the manuscript, or in the decision to publish the results.

\section{References}

1. Lamhamedi, M.S.; Lambany, G.; Margolis, H.A.; Renaud, M.; Veilleux, L.; Bernier, P.Y. Growth, physiology and leachate losses in Picea glauca seedlings (1+0) grown in air-slit containers under different irrigation regimes. Can. J. For. Res. 2001, 31, 1968-1980. [CrossRef]

2. Lamhamedi, M.S.; Labbé, L.; Margolis, H.A.; Stowe, D.C.; Blais, L.; Renaud, M. Spatial variability of substrate water content and growth of white spruce seedlings. Soil Sci. Soc. Am. J. 2006, 70, 108-120. [CrossRef]

3. Stowe, D.C.; Lamhamedi, M.S.; Margolis, H.A. Water relations, cuticular transpiration, and bud characteristics of air-slit containerized Picea glauca seedlings in response to controlled irrigation regime. Can. J. For. Res. 2001, 31, 1922-1929. [CrossRef]

4. Stowe, D.C.; Lamhamedi, M.S.; Carles, S.; Fecteau, B.; Margolis, H.A.; Renaud, M.; Bernier, P. Managing irrigation to reduce nutrient leaching in containerized white spruce seedling production. New For. 2010, 40, 185-204. [CrossRef]

5. Lamhamedi, M.S.; Chamberland, H.; Bernier, P.Y.; Tremblay, F.M. Clonal variation in morphology, growth, physiology, anatomy and ultrastructure of container-grown white spruce somatic seedlings. Tree Physiol. 2000, 20, 869-880. [CrossRef] [PubMed]

6. Wahid, N.; Lamhamedi, M.S.; Rainville, A.; Beaulieu, J.; Margolis, H.A. Genetic control and nursery-plantation genotypic correlations for growth characteristics of white spruce somatic clones. J. Sustain. For. 2013, 32, 576-593. [CrossRef]

7. Wahid, N.; Lamhamedi, M.S.; Beaulieu, J.; Margolis, H.; Deblois, J. Genetic parameters and clonal variation in growth and nutritional traits in containerized white spruce somatic seedlings. Bot. Gallica 2012, 159, 373-384. [CrossRef]

8. Lamhamedi, M.S. Variabilité spatiale et variations extrêmes des teneurs en eau du substrat en pépinière forestière: Facteurs aggravants de l'insuffisance racinaire. Ministère des Ressources naturelles et de la Faune, Direction de la recherche forestière. Avis De Rech. For. 2011, 28, 1-2. 
9. MFFP. Guide de Terrain. Inventaire de Qualification des Plants Résineux Cultivés en Récipients; Gouvernement du Québec: Québec, QC, Canada, 2019; p. 114.

10. Lamhamedi, M.S. 2013. Principaux facteurs et techniques culturales affectant la germination des semences et la croissance des plants en pépinière forestière. In Atelier sur les Semences Forestières: Un Maillon Clé des Plantations de Grande Valeur; Gouvernement du Québec, Ministère des Ressources naturelles du Québec: Québec, QC, Canada, 2013; pp. 22-25.

11. Lamhamedi, M.S. Variabilité de la Qualité de la Silice et Comparaison des Effets de la Silice et de la Calcite sur la Croissance et la Nutrition Minérale des Plants en Pépinière Forestière. Journée de Transfert de Connaissances; Office des Producteurs de Plants Forestiers du Québec: Québec, QC, Canada, 2015; p. 66.

12. Lamhamedi, M.S.; Bernier, P.Y.; Hébert, C.; Jobidon, R. Physiological and growth responses of three types of containerized Picea mariana seedlings outplanted with and without vegetation control. For. Ecol. Manag. 1998, 110, 13-23. [CrossRef]

13. Lamhamedi, M.S.; Bernier, P.Y.; Hébert, C. Effect of shoot size on the gas exchange and growth of containerized Picea mariana seedlings under different watering regimes. New Forests 1997, 13, 209-223. [CrossRef]

14. Caron, J. La tourbe et les milieux artificiels. In Écologie des Tourbières du Québec-Labrador; Payette, S., Rochefort, L., Eds.; Presses de l’Université Laval: Québec, QC, Canada, 2001; pp. 399-410.

15. Lamhamedi, M.S.; Renaud, M.; Veilleux, L. Les effets de l'augmentation du pH des substrats sur la croissance des plants forestiers produits dans les pépinières forestières? In Production de Plants Forestiers au Québec: La Culture de L'innovation, Proceedings of the Colloque de Transfert de Connaissances et de Savoir-Faire, Carrefour Forêt Innovations, Québec, QC, Canada, 4-6 October 2011; Colas, F., Lamhamedi, M.S., Eds.; Gouvernement du Québec: Québec, QC, Canada, 2011; pp. 33-45.

16. Rikala, R.; Jozefek, H.J. Effect of dolomite lime and wood ash on peat substrate and development of tree seedlings. Silva Fenn. 1990, 24, 323-334. [CrossRef]

17. Rippy, J.F.M. Factors Affecting pH Establishment and Maintenance in Peat Moss-Based Substrates. Ph.D. Thesis, North Carolina State University, Raleigh, NC, USA, 2005.

18. South, D.B. Optimum pH for growing pine seedlings. Tree Plant. Notes 2017, 60, 49-62.

19. South, D.B.; Nadel, R.L.; Enebak, S.A.; Bickerstaff, G. Sulfur and lime affect soil pH and nutrients in a sandy Pinus taeda nursery. Reforesta 2017, 4, 12-20. [CrossRef]

20. Lamhamedi, M.S.; Renaud, M.; Auger, I.; Fortin, J.A. Granular calcite stimulates natural mycorrhization and growth of white spruce seedlings in peat-based substrates in forest nursery. Microorganisms 2020, 8, 1088. [CrossRef]

21. Lamhamedi, M.S.; Renaud, M.; Auger, I. Stimulation par la calcite de la colonisation ectomycorhizienne des racines des plants d'épinette blanche $(2+0)$ et augmentation de leur croissance dans les substrats tourbeux en pépinière forestière. Gouvernement du Québec, ministère des Forêts, de la Faune et des Parcs. Mémoire De Rech. For. 2020, 182, 50.

22. Lamhamedi, M.S.; Renaud, M.; Desjardins, P.; Veilleux, L. Root growth, plug cohesion, mineral nutrition, and carbohydrate content of $(1+0)$ Picea mariana seedlings in response to a short-day treatment. Tree Plant. Notes 2013, 56, 35-46.

23. Girard, D.; Gagnon, J.; Langlois, C.-G. PLANTEC: Un logiciel pour gérer la fertilisation des plants dans les pépinières forestières. Gouvernement du Québec, ministère des Ressources naturelles, Direction de la recherche forestière. Note De Rech. For. 2001, $111,1-8$.

24. Kalra, Y.P.; Maynard, D.G. Méthodes D'analyses des Sols Forestiers et des Tissus Végétaux; Rapport d'information NOR-X-319F; Forêts Canada, Région du Nord-Ouest, Centre de foresterie du Nord: Edmonton, AB, Canada, 1992; p. 129.

25. Gagnon, J.; DeBlois, J. Effects of foliar urea fertilization on nitrogen concentrations of containerized $2+0$ jack pine seedlings produced in forest nurseries. Tree Plant. Notes 2017, 60, 44-50.

26. Timmer, V.R.; Armstrong, G.; Miller, B.D. Steady-state nutrient preconditioning and early outplanting performance of containerized black spruce seedlings. Can. J. For. Res. 1991, 21, 585-594. [CrossRef]

27. Ågren, G.I. Theory for growth of plants derived from the nitrogen productivity concept. Physiol. Plant. 1985, 64, 17-28. [CrossRef]

28. Ledig, F.T.; Bormann, F.H.; Wenger, K.F. The distribution of dry matter growth between shoot and roots in loblolly pine. Bot. Gaz. 1970, 131, 349-359. [CrossRef]

29. Qualtiere, E.J. Variation in Germination Response to Temperature among Collections of Three Conifers from the Mixed Wood Forest. Ph.D. Thesis, University of Saskatchewan, Saskatoon, SK, Canada, 2008.

30. Timmer, V.R.; Parton, G. Monitoring nutrient status of containerized seedlings. In Proceedings of the Ontario Ministry of Natural Ressources Nurseryman's Meeting, Thunder Bay, ON, Canada, 7-11 June 1982; pp. 48-58.

31. White, P.J.; Broadley, M.R. Calcium in plants. Ann. Bot. 2003, 92, 487-511. [CrossRef]

32. Hochmal, A.K.; Shulze, S.; Trompelt, K.; Hippler, M. Calcium-dependent regulation of photosynthesis. Biochim. Biophys. Acta 2015, 1847, 993-1003. [CrossRef] [PubMed]

33. Desilva, D.L.R.; Hetherington, A.M.; Mansfield, T.A. Synergism between calcium and abscisic acid in preventing stomatal opening. New Phytol. 1985, 100, 437-482.

34. Feagley, S.E.; Fenn, L.B. Using Soluble Calcium to Stimulate Plant Growth; Texas Agricultural Extension service; The Texas A\&M University System: College Station, TX, USA, 1998; 4p.

35. Yang, B.Z.; Liu, Z.B.; Zhou, S.D.; Ou, L.J.; Dai, X.Z.; Ma, Y.Q.; Zhang, Z.Q.; Chen, W.C.; Li, X.F.; Liang, C.L.; et al. Exogenous Ca ${ }^{2+}$ alleviates waterlogging-caused damages to pepper. Photosynthetica 2016, 54, 620-629. [CrossRef] 
36. Gagnon, J.; Lamhamedi, M.S. Les concentrations foliaires en azote recommandées au Québec pour les essences résineuses produites en récipients sont-elles adéquates. In Production de Plants Forestiers au Québec: La Culture de L'innovation, Proceedings of the Colloque de Transfert de Connaissances et de Savoir-Faire, Carrefour Forêt Innovations, Québec, QC, Canada, 4-6 October 2011; Colas, F., Lamhamedi, M.S., Eds.; Gouvernement du Québec: Québec, QC, Canada, 2011; pp. 47-51.

37. Lopez-Lefebre, L.R.; Rivero, R.M.; García, P.C.; Sanchez, E.; Ruiz, J.M.; Romero, L. Effect of calcium on mineral nutrient uptake and growth of tobacco. J. Sci. Food Agric. 2001, 81, 1334-1338. [CrossRef]

38. Zhao, H.J.; Tan, J.-F. Role of calcium ion in protection against heat and high irradiance stress-induced oxidative damage to photosynthesis of wheat leaves. Photosynthetica 2005, 43, 473-476. [CrossRef]

39. Halman, J.M.; Schaberg, P.G.; Hawley, G.J.; Eagar, C. Calcium addition at the Hubbard Brook Experimental Forest increases sugar storage, antioxidant activity and cold tolerance in native spruce (Picea rubens). Tree Physiol. 2008, 28, 855-862. [CrossRef]

40. Palta, J.P. Role of calcium in plant responses to stresses: Linking basic research to the solution of practical problems. HortScience 1996, 31, 51-57. [CrossRef]

41. Percival, G.; Barnes, S. Calcium-induced freezing and salinity tolerance in evergreen oak and apple cv. Golden Crown. Arbor. Urban For. 2008, 34, 191-199.

42. Lamhamedi, M.S. Principaux facteurs influençant le développement racinaire et effets de l'irrigation sur la croissance et la physiologie des racines en pépinière forestière. In Recueil des Conférences et des Résumés du 4e Atelier sur la Production de Plants Forestiers du Québec; Gouvernement du Québec, Ministère des Ressources Naturelles et de la Faune [cd-rom]: Sainte-Foy, QC, Canada, 2006; p. 2.

43. Lamhamedi, M.S. Lamhamedi, M.S. La masse des racines pourrait-elle être utilisée comme un critère de qualité avant la livraison des plants en site de reboisement? In Production de Plants Forestiers au Québec: La Culture de L'innovation, Proceedings of the Colloque de Transfert de Connaissances et de Savoir-Faire, Carrefour Forêt Innovations, Québec, QC, Canada, 4-6 October 2011; Colas, F., Lamhamedi, M.S., Eds.; Gouvernement du Québec: Québec, QC, Canada, 2011; pp. 65-69.

44. Lamhamedi, M.S.; Renaud, M.; Desjardins, P.; Veilleux, L. Évaluation de la qualité morpho-physiologique du système racinaire des plants du mélèze laricin: Les racines foncées ou noires peuvent-elles être considérées mortes? Gouvernement du Québec, ministère des Ressources naturelles et de la Faune du Québec, Direction de la recherche forestière. Avis Tech. SGRE 2011, 3, 1-33.

45. Gagnon, J.; Lamhamedi, M.S. L'inoculation des plants résineux en récipients par des spores de champignons ectomycorhiziens à l'automne pourrait-elle contribuer à réduire les problèmes d'insuffisance racinaire dans les pépinières forestières du Québec? In Production de Plants Forestiers au Québec: La Culture de L'innovation, Proceedings of the Colloque de Transfert de Connaissances et de Savoir-Faire, Carrefour Forêt Innovations, Québec, QC, Canada, 4-6 October 2011; Colas, F., Lamhamedi, M.S., Eds.; Gouvernement du Québec: Québec, QC, Canada, 2011;pp. 27-32.

46. Rillig, M.C.; Mummy, D.L. Mycorrhizas and soil structure. New Phytol. 2006, 171, 4-53. [CrossRef]

47. Read, D.J. The mycorrhizal mycelium. In Mycorrhizal Functioning: An Integrative Plant-Fungal Process; Allen, M., Ed.; Chapman and Hell: New York, NY, USA, 1992; pp. 102-133.

48. Kropp, B.R.; Langlois, C.-G. Ectomycorrhizae in reforestation. Can. J. For. Res. 1990, 20, 438-451. [CrossRef]

49. Lamhamedi, M.S.; Abourouh, M.; Fortin, J.A. Technological transfer: The use of ectomycorrhizal fungi in conventional and modern forest tree nurseries in northern Africa. In Advances in Mycorrhizal Science and Technology; Khasa, D., Piché, Y., Coughlan, A.P., Eds.; NRC Research Press: Ottawa, ON, Canada, 2009; pp. 139-152.

50. Marx, D.H.; Cordell, C.E. The use of specific ectomycorrhizas to improve artificial forestation practices. In Biotechnology of Fungi for Improving Plant Growth; Whipps, J.M., Lumsden, R.D., Eds.; Cambridge University Press: Cambridge, UK, 1989 ; pp. 1-25.

51. Perry, D.A.; Molina, R.; Amaranthus, M.P. Mycorrhizae, mycorrhizospheres, and reforestation: Current knowledge and research needs. Can. J. For. Res. 1987, 17, 929-940. [CrossRef]

52. Marx, D.H. Ectomycorrhizae as bilogical deterrents to pathogenic root infections. Annu. Rev. Phytopathol. 1972, 10, 429-454. [CrossRef]

53. Zak, B. Role of mycorrhizae in root disease. Annu. Rev. Phytopathol. 1964, 2, 377-392. [CrossRef]

54. Whipps, J.M. Prospects and limitations for mycorrhizas in biocontrol of root pathogens. Can. J. Bot. 2004, 82, 1198-1227. [CrossRef]

55. Otgonsuren, B.; Lee, M.J. Ectomycorrhiza enhanced the cold-acclimation growth and freeze tolerance of Scots pine (Pinus sylvestris L.). Taiwan, J. For. Sci. 2013, 28, 97-111.

56. Lamhamedi, M.S.; Fortin, J.A.; Bernier, P.Y. La génétique de Pisolithus sp.: Une nouvelle approche de biotechnologie forestière pour assurer une meilleure survie des plants en conditions de sécheresse. Sécheresse 1991, 2, 251-258.

57. Lamhamedi, M.S.; Bernier, P.Y.; Fortin, J.A. Hydraulic conductance and soil water potential at the soil-root interface of Pinus pinaster seedlings inoculated with different dikaryons of Pisolithus sp. Tree Physiol. 1992, 10, 231-244. [CrossRef]

58. Lehto, T.; Zwiazek, J.J. Ectomycorrhizas and water relations of trees: A review. Mycorrhiza 2011, 21, 71-90. [CrossRef] [PubMed]

59. Read, D.J.; Boyd, R. Water relations of mycorrhizal fungi and their host plants. In Water, Fungi and Plants; Ayres, P.G., Body, L., Eds.; Cambridge University Press: Cambridge, UK, 1986; pp. 287-304.

60. Landis, T.D.; Tinus, R.W.; McDonald, S.E.; Barnett, J.P. The Container Tree Nursery Manual. Vol. 4: Seedling Nutrition and Irrigation. In Handbook Agric. n 674, U.S.D.A.; Forest Service: Washington, DC, USA, 1989; 119p. 